\title{
Hegemonia, internacionalização do estado e direito internacional segundo a teoria neogramsciana ${ }^{1}$
}

Flávio Paulo Meirelles Machado²

\section{Resumo}

O trabalho tem como objetivo apresentar a Teoria Neogramsciana como instrumento para inquirição do processo da “internacionalização do Estado". Examinase a configuração das relações humanas, pautadas na hegemonia, que ordenam as atividades produzidas no sistema de redes internacionais e modelam as ações por noções de “obrigações internacionais". Em primeiro, trata-se de uma apresentação teórica do trabalho de Gramsci contida nos "Cadernos do Cárcere" e sua revisão exposta por Cox em seu artigo intitulado "Social Forces, States and World Orders". O intuito de utilizar-se desse marco teórico é abordar de forma crítica o processo de globalização e instrumentalização do Direito dentro desse processo. Para isso, ilustra-se analiticamente o contexto histórico da pax britannica e da pax americana em busca de um conhecimento do fenômeno atual da globalização do ponto de vista empírico, em conjunção com aquilo que é exposto teoricamente na primeira parte do trabalho. Em seguida, acercar-se sobre o papel do Direito, seu desempenho que pode ser tanto contra-hegemônico e harmonizador das relações sociais e discute-se a possibilidade de mudanças da ordem internacional. Conclui-se que a globalização hegemônica pode ser atenuada pela globalização de baixo para cima. Nesse contexto, convém ressaltar o Direito Internacional como uma categoria que deve ser utilizada para transformação social. O Direito Internacional pode ser a forma de reestruturação do relacionamento entre os estados e a economia internacional. E para isso, somente ações de organizações, grupos, Estados e movimentos contra-hegemônicos são capazes de produzir um Direito alternativo e mais justo.

1 Este artigo está cadastrado no Digital Object Identifier System sob o número doi: 10.5102/ prismas.2010.07.1.07 Disponível em: <www.publicaçõesacadêmicas.uniceub.br>.

2 Advogado, especialista em Direito Ambiental Internacional pelo Instituto das Nações Unidas para Treinamento e Pesquisa - UNITAR, especialista em Direito Público pela Faculdade FORTIUM, Bacharel em Relações Internacionais pelo UNICEUB. 
Palavras-chave: Hegemonia. Internacionalização do Estado. Globalização. Teoria Neogramsciana. Direito Internacional.

\section{Introdução}

“A teoria é sempre para alguém e para algum propósito." Essa é uma frase repetida em vários textos de Robert Cox, que desenvolve uma abordagem Neogramsciana das Relações Internacionais. Utilizar-se do materialismo histórico de Gramsci, em nossos dias, é uma forma alternativa encontrada pela esquerda para exercer influência na política internacional.

Apesar de essa ferramenta teórica ser um instrumento para a "ditadura do proletariado", a sua principal contribuição não é somente o caminho revolucionário, mas sim, proporcionar o conhecimento de que as estruturas sociais são reflexos históricos das relações humanas e que a ordem constituída pode ser modificada por meio de ações coletivas que criem novos padrões de relacionamento e que, por consequência, proporcionem uma nova ordem.

Para os acadêmicos de Relações Internacionais e Direito Internacional, a teoria coliga a contribuição sobre a influência do poder e dos interesses na produção intelectual que sempre será, em congruência com a idéia contida na primeira frase citada, uma produção política.

O trabalho tem como objetivo central apresentar a Teoria Neogramsciana como instrumento para inquirição do processo da "internacionalização do Estado". Examina-se aqui a configuração das relações humanas, pautadas na hegemonia, que ordenam as atividades produzidas no sistema de redes internacionais e modelam as ações por noções de "obrigações internacionais", as quais podem ser entendidas como Direito Internacional.

O pensamento exposto aqui se dedica a estudar as fontes de desigualdades entre os atores das relações internacionais e as formas como essas podem ser superadas, além de refletir sobre as condições históricas da desigualdade e as formas a favor de uma ordem mundial mais justa.

A primeira parte do trabalho trata-se de uma apresentação teórica do trabalho de Gramsci contida nos "Cadernos do Cárcere" e sua revisão exposta 
por Cox em seu artigo intitulado "Social Forces, States and World Oders". O intuito de utilizar-se desse marco teórico é abordar de forma crítica o processo de globalização e instrumentalização do Direito dentro desse processo.

Nesse sentido, a primeira parte do trabalho é composta por uma apresentação teórica do trabalho desses autores, com ênfase nas relações internacionais. Ambos têm, guardadas as devidas proporções, o mesmo foco analítico e são representantes da Teoria Crítica. Essa apreciação confere a utilização de conceitos sobre hegemonia, sociedade civil, bloco histórico que são cruciais para a discussão da política internacional, principalmente, econômica.

A compreensão dessa teoria pressupõe o entendimento histórico da realidade. Portanto, na segunda parte do artigo, ilustram-se, de forma branda, esses conceitos dentro do contexto histórico da pax britannica e da pax americana em busca de um conhecimento mais palpável dos fenômenos da hegemonia, da internacionalização e da geminação daquilo que hoje se entende por globalização. É a verificação no plano histórico dos conceitos apresentados no primeiro capítulo do trabalho. Também é demonstrado, no segundo capítulo, o antagonismo presente nesse processo histórico.

Em seguida, no capítulo três, acerca-se sobre o Direito Internacional e analisa-se se esse pode ser catalisador de mudanças social e redutor dos antagonismos presentes na globalização. Verifica-se o que Gramsci entendia por Direito e qual é a proposta da Teoria Neogramsciana para o Direito Internacional.

A tarefa de apresentar a Teoria Neogramsciana justifica-se pela busca de um conhecimento capaz de iluminar quais são as relações entre as forças sociais e materiais que permitem que certos valores moldem as relações internacionais.

O pensamento exposto aqui se dedica a estudar as fontes de desigualdades entre os atores das relações internacionais e as formas como essas desigualdades podem ser superadas. Argumenta-se que o atual sistema capitalista dissimula e possibilita injustiças. O texto procura esclarecer que a globalização é um cenário amplo para transformação da ordem existente em nome de uma ordem mais justa e que o Direito, se representado por forças ativas, pode superar essas injustiças. 


\section{A teoria}

Para as teorias mais tradicionais existe a preponderância dos Estados nas relações internacionais; a sociedade civil é separada do ente estatal e ambos pertencem a esferas autônomas das relações internacionais, uma doméstica e outra internacional.

Contudo, para a Teoria Gramsciana, a sociedade civil, os Estados, a ordem internacional e o processo de produção são elementos de uma mesma realidade, separados somente para mera interpretação analítica da mente humana. A teoria não é divorciada da mente humana, representa o eu e tem uma ideologia humana construindo-a. A teoria é uma ferramenta de interpretação e compreensão da realidade.

Por isso, primeiro apresenta-se neste trabalho uma teoria para analisar a internacionalização do Estado. A Teoria aqui presente se pergunta sobre como os fenômenos acontecem, não aceita as instituições e forças sociais como elementos exógenos, preocupa-se com a origem histórica e não separa o complexo social do político. Por isso, antes de se explicar o objeto internacionalização do Estado, há de se entender o que é Estado, sociedade, estruturas, ordem etc.

A compreensão do materialismo histórico pressupõe o entendimento do que são estruturas históricas. A estrutura é uma limitação, assim como um tipo ideal, uma representação simples de uma realidade complexa. ${ }^{3}$ Em sentido restrito, a estrutura ou quadro de ação é uma figura da configuração de forças. ${ }^{4}$

Estruturas são respostas coletivas às condições materiais da existência humana durante um período de tempo. Moldam a percepção social da realidade, transformam as mentes e ações individuais. Embora não determinem as ações dos indivíduos, impõem pressões e restrições. Os indivíduos podem resistir a elas, transformá-las ou superá-las, mas jamais ignorá-las. Quer dizer, essa figura compartilhada entre muitas pessoas define a realidade para elas. Partindo do pressuposto de que os indivíduos pensam o mesmo sobre a natureza da realidade, eles

${ }^{3}$ COX, Robert W. Social forces, states and world orders: beyond international relations theory. In: COX, Robert; SINCLAIR, Timothy. Approaches to world order. Cambridge: Cambridge University Press, 1996. p. 100.

4 COX, Robert W. Social forces, states and world orders: beyond international relations theory. In: COX, Robert; SINCLAIR, Timothy. Approaches to world order. Cambridge: Cambridge University Press, 1996. p. 97. 
agem conforme os mesmos pressupostos. Aliás, conforme suas ações e palavras são apresentadas perante os fatos, isto é, comportamentos baseados em um específico entendimento a respeito do mundo, tendem a reproduzir aquela realidade compartilhada. ${ }^{5}$

Três categorias de forças interagem com a estrutura: (1) potencialidades materiais, (2) ideias (intersubjective meanings e collective images) e (3) instituições. ${ }^{6}$

As potencialidades materiais se referem à estrutura econômica da sociedade. Incluem também as capacidades tecnológicas e organizacionais. ${ }^{7}$ Isso não significa somente o método pelo qual se produz uma mercadoria, mas as relações sociais que comandam a produção e a transformação de algo pela sociedade.

As ideias são divididas em duas espécies. Têm-se os significados intersubjetivos como uma dessas espécies. Intersubjective meanings ou significados intersubjetivos são conceitos compartilhados que sustentam hábitos e expectativas quanto ao comportamento social. Para Cox, na política internacional contemporânea, um exemplo de conceito compartilhado dentro de um período histórico é a noção que as populações são comandadas e divididas por Estados. Essa noção de Estado como centro das relações internacionais é uma visão histórica contida e expressa uma visão de origem vestefaliana prolongada. $\mathrm{O}$ autor transcursa que a concepção estatal de vida em grupo resulta de transformações sociais ocorridas durante séculos, pois nem sempre as relações humanas foram representadas assim. ${ }^{8}$

O outro tipo de ideias são as imagens coletivas da ordem social que os grupos sociais possuem. Trata-se de diferentes visões sobre um mesmo tema, tais como a justiça, equidade e bens públicos. Enquanto os significados intersubjetivos são a pedra angular de uma estrutura histórica, as imagens coletivas podem ser

5 COX, Robert W. Critical political economy. In: HETTNE, Björn (Ed.) International political economy: understanding global disorder. Halifax: Fernwood, 1995. p. 33.

${ }^{6}$ COX, Robert W. Social forces, states and world orders: beyond international relations theory. In: COX, Robert; SINCLAIR, Timothy. Approaches to world order. Cambridge: Cambridge University Press, 1996. p. 98.

7 COX, Robert W. Social forces, states and world orders: beyond international relations theory. In: COX, Robert; SINCLAIR, Timothy. Approaches to world order. Cambridge: Cambridge University Press, 1996. p. 98

8 COX, Robert W. Social forces, states and world orders: beyond international relations theory. In: COX, Robert; SINCLAIR, Timothy. Approaches to world order. Cambridge: Cambridge University Press, 1996., p. 98. 
múltiplas e opostas. Os choques entre as imagens coletivas correspondem a possíveis capacidades alternativas para uma nova estrutura histórica. ${ }^{9}$

As instituições "são o modo como as práticas sociais, desenvolvidas em reação a problemas particulares que confrontam uma sociedade, transformamse em rotinas compostas por conjuntos específicos de regras." ${ }^{10}$

As instituições são formas de se lidar com o conflito, minimizando a necessidade de se recorrer à força física, visando à estabilização ou perpetuação de uma determinada ordem. Inicialmente, procuram reforçar o poder das forças sociais dominantes, cultivando imagens coletivas compatíveis. É possível que essas mesmas instituições tornem-se campos de conflitos entre tendências opostas ou, até mesmo, existam instituições formadas exclusivamente para combater poderes dominantes. Portanto, existe uma conexão óbvia entre as instituições e o conceito de hegemonia de Gramsci. ${ }^{11},{ }^{12}$

Isso significa que normalmente as instituições são as formas aceitas para organizar uma esfera social e vão desde as organizações tradicionais como o matrimônio, passando pelos Estados nacionais, até as mais internacionalizadas, como, por exemplo, Organização das Nações Unidas - ONU, Fundo Monetário Internacional - FMI, Banco Mundial. Elas podem ser organizadas com diferentes graus de formalidade, sanções ou regras como é o caso dos regimes - arranjos duradouros que regulam determinadas áreas específicas. ${ }^{13}$

9 COX, Robert W. Social forces, states and world orders: beyond international relations theory. In: COX, Robert; SINCLAIR, Timothy. Approaches to world order. Cambridge: Cambridge University Press, 1996. p. 99.

${ }^{10}$ COX, Robert W. Rumo a uma concepção pós-hegemônica de ordem mundial: reflexões sobre a relevância de Ibn Kaldun. In: ROSENAU, James N.; CZEMPIEL, Ernst-Otto. Governança sem governo: ordem e transformação na política mundial. Brasília: UnB, 2000. p. 190.

${ }^{11}$ COX, Robert W. Social forces, states and world orders: beyond international relations theory. In: COX, Robert; SINCLAIR, Timothy. Approaches to world order. Cambridge: Cambridge University Press, 1996. p. 99.

${ }^{12}$ Ver o conceito de hegemonia adiante.

${ }^{13}$ COX, Robert W. Rumo a uma concepção pós-hegemônica de ordem mundial: reflexões sobre a relevância de Ibn Kaldun. In: ROSENAU, James N.; CZEMPIEL, Ernst-Otto. Governança sem governo: ordem e transformação na política mundial. Brasília: UnB, 2000. p. 190-191. 
Prismas: Dir., Pol. Publ. e Mundial., Brasília, v. 7, n. 1, p. 173-221, jan./jun. 2010 Hegemonia, internacionalização do estado e direito internacional segundo ...

Para esclarecer a temática de estruturas históricas, Cox apresenta três esferas interdependentes: a) forças sociais, b) formas de Estados, c) ordens mundiais. ${ }^{14}$

A primeira corresponde ao modo de organização da produção, em especial, das forças sociais geradas pelo processo de produção. Mudanças na produção podem gerar ou modificar a condição de certas classes, provocando modificações na estrutura estatal que sucessivamente podem alterar a relação entre Estados. ${ }^{15}$

Formas de Estados abrangem o complexo Estado/sociedade civil. ${ }^{16}$ Reconhece-se que cada Estado possui formas e estruturas diferenciadas, e que são historicamente gerados por uma configuração derivada das capacidades materiais, ideias e instituições.

Diz-se que “ordem” é uma relação não casual entre os constituintes, atores sociais, que relacionam entre si e acordam em um modelo de interações (que podem ser conflituosas), baseando-se em elementos normativos e na promoção de certos valores e objetivos específicos. Já para Cox, ordem é “todo modelo ou regularidade de interação que encontramos em qualquer situação social [...]"17e a ordem mundial é a configuração de forças que determinam a problemática da guerra e da paz para os Estados. ${ }^{18} ;{ }^{19}$

${ }^{14}$ COX, Robert W. Social forces, states and world orders: beyond international relations theory. In: COX, Robert; SINCLAIR, Timothy. Approaches to world order. Cambridge: Cambridge University Press, 1996. p. 100.

${ }^{15}$ COX, Robert W. Social forces, states and world orders: beyond international relations theory. In: COX, Robert; SINCLAIR, Timothy. Approaches to world order. Cambridge: Cambridge University Press, 1996 p. 100.

${ }^{16}$ COX, Robert W. Social forces, states and world orders: beyond international relations theory. In: COX, Robert; SINCLAIR, Timothy. Approaches to world order. Cambridge: Cambridge University Press, 1996 p. 100.

${ }^{17}$ COX, Robert W. Rumo a uma concepção pós-hegemônica de ordem mundial: reflexões sobre a relevância de Ibn Kaldun. In: ROSENAU, James N; CZEMPIEL, Ernst-Otto. Governança sem governo: ordem e transformação na política mundial. Brasília: UnB, 2000. p. 189.

${ }^{18}$ COX, Robert W. Social forces, states and world orders: beyond international relations theory. In: COX, Robert; SINCLAIR, Timothy. Approaches to world order. Cambridge: Cambridge University Press, 1996. p. 100.

${ }^{19}$ Dentro dessa perspectiva, Cox apresenta uma preocupação que corresponde ao principal objetivo dos regimes ambientais internacionais: "como introduzir na ordem as normas de conduta que darão forma ao comportamento individual e coletivo." COX, Robert W. Rumo a uma concepção pós-hegemônica de ordem mundial: reflexões sobre a relevância de Ibn Kaldun. In: ROSENAU, James N; CZEMPIEL, Ernst-Otto. Governança sem governo: ordem e transformação na política mundial. Brasília: UnB, 2000. p. 190. 


\subsection{Estado, sociedade, hegemonia, bloco histórico, guerra de posição}

Muitas abordagens apontam o declínio dos Estados nacionais como forma de organização política dos seres humanos nas relações internacionais. Segundo vários autores e suas teses, tais como, o "Choque de Civilizações" de Huntington, o neoliberalismo de Keohane ou o neomarxismo de Wallerstein identificam tal fato. Em contrapartida, há pressões no sentido contrário, as quais reconhecem o papel fundamental do Estado e afirmam que seu fortalecimento é imprescindível para os anseios da sociedade mundial.

A Teoria Crítica de Cox baseada em Gramsci fornece um compasso para se visualizar os Estados em sua forma atual e assim como em uma fase pós-moderna. Legatário de Marx, Gramsci concebe uma teoria do Estado muito similar ao seu predecessor. Assim como Marx, ele refuta a ideia do sistema do direito hegeliano abalizado na prioridade do Estado sobre a sociedade civil. Mas de qualquer forma, para ambos os autores, a solução dos problemas políticos encontra-se na democracia - a absorção do Estado pela sociedade civil. ${ }^{20}$

Para Marx, o Estado - conjunto de instituições políticas detentoras da violência concentrada e organizada da sociedade - é uma superestrutura embasada na estrutura, local das relações de produção e onde se desenvolvem as relações materiais da existência. Ou seja, local da estrutura econômica e as formas de consciência. O Estado é um momento secundário subordinado ao momento primário, o sistema social. Na verdade, Estado só existe em decorrência da vida civil. Quanto a isso, Marx afirma.

A vida material dos indivíduos, que não dependem em absoluto de sua pura 'vontade', o seu modo de produção e a forma de relações, que se condicionam reciprocamente, são a base real do Estado em todos os estágios nos quais ainda é necessária a divisão de trabalho, totalmente independente da vontade dos indivíduos. Estas relações reais não são absolutamente criadas pelo poder do Estado; são, antes, essas relações o poder que cria o Estado. ${ }^{21}$

\footnotetext{
${ }^{20} \mathrm{O}$ oposto à democracia é a ditadura, situação de um grupo dominante, não hegemônico, que domina toda a sociedade pela coerção, utilizando-se do aparelho estatal, sociedade política.

${ }^{21}$ MARX, Karl apud BOBBIO, Norberto; MATTEUCI, Nicola; PASQUINO, Gianfranco. Dicionário de política. Brasília: Editora UnB, 2000. p. 740.
} 
Todavia, em seus cadernos, Gramsci se distingue de Marx. Ele entende que a sociedade civil não pertence à estrutura, mas à superestrutura. Para ele, existem dois níveis de estruturas: a estrutura, que é a esfera econômica (e o passado histórico) e a superestrutura, composta pela sociedade civil e sociedade política.

Segundo Gramsci, o centro da relação entre estrutura e a superestrutura não pode ser reduzido à esfera econômica. O autor firma que "não é a estrutura econômica que determina a ação política, mas sim a interpretação que se tem dela e das chamadas leis que governam o seu movimento". ${ }^{22}$

Gramsci emprega o termo "catarse" para indicar o momento de passagem do momento primário (econômico/egoísta/da necessidade) para o momento secundário (político/ético/liberdade). Em outros termos, a estrutura econômica torna o homem passivo e egoísta; pela "catarse", os homens elaboram por meio da ética-política (sociedade civil) uma estrutura política secundária, que só pode existir se os homens se reconhecerem como sujeitos ativos da história, livres para transformar a realidade. Esse segundo momento chamado de superestrutura é composto pelo consenso e pela força que são capazes de transcender a premissa da estrutura. ${ }^{23}$ Sendo assim, o momento secundário passa a ser subordinador do momento primário. Bobbio destrincha esse tema da seguinte forma, in verbis

Uma vez considerando o momento da sociedade civil como o momento através do qual se realiza a passagem da necessidade à liberdade, as ideologias - das quais a sociedade civil é a sede histórica - são vistas, não apenas como justificação póstuma de um poder cuja formação histórica depende das condições materiais, mas como forças formadoras e criadoras de nova história, colaboradoras na formação de um poder que se vai constituindo, e não tanto como justificadores de um poder já constituído. ${ }^{24}$

Aquele segundo momento é a superestrutura quando se constitui o Estado no sentido orgânico de Gramsci. Ou seja, a junção da sociedade política e sociedade civil. Destarte, a sociedade civil é inseparável do Estado, conjuntamente eles

22 GRAMSCI, Antonio apud BOBBIO, Norberto. Ensaios sobre Gramsci e o conceito de sociedade civil. São Paulo: Paz e Terra, 1999. p. 59.

${ }^{23}$ GRAMSCI, Antonio. apud. BOBBIO, Norberto. Ensaios sobre Gramsci e o conceito de sociedade civil. São Paulo: Paz e Terra, 1999. p. 59-60.

${ }^{24}$ GRAMSCI, Antonio. apud. BOBBIO, Norberto. Ensaios sobre Gramsci e o conceito de sociedade civil. São Paulo: Paz e Terra, 1999. p. 62. 
constituem e refletem uma ordem hegemônica. O Estado não ocupa sozinho a superestrutura, pois, para Gramsci, o Estado é entendido como um equilíbrio entre sociedade política e sociedade civil.

A sociedade política é o aparelho governamental ou público, coercitivo. É semelhante àquilo que os realistas denominam como Estado. ${ }^{25}$

A sociedade civil é composta pelas diferentes formas de associações voluntárias e consiste no momento da transição da estrutura econômica para a sociedade política. A sociedade civil seria o aparelho privado da hegemonia, a esfera na qual se formam as identidades, disputas ideológicas, atividades intelectuais. Sociedade civil corresponde ao bloco de interesses, estágio pelo qual interesses menores tornam-se universalizados. ${ }^{26}$ A sociedade civil de Gramsci é composta por aqueles organismos habitualmente ditos privados, quais sejam ideológicos, culturais, espirituais e intelectuais. Nela se constrói toda a história no sentido hegemônico pelo qual um grupo social alinha toda a sociedade civil. Sociedade civil é a rede de instituições e práticas com alguma autonomia do Estado.

Ainda que a estrutura econômica possa ser preponderante nas relações sociais, Gramsci se preocupa com o papel educativo do Estado, "na sua importância para a construção das alianças que poderiam receber apoio de diferentes estratos sociais e no papel de provedor de 'liderança' cultural e moral." ${ }^{27} \mathrm{O}$ desígnio do Estado democrático é a formação e o desenvolvimento da sociedade civil, atração dos representantes das demais camadas intelectuais mediante uma filosofia e um programa escolar que promovam o consenso e visem enfraquecer o papel da coerção e que permitam subordinar a estrutura. Dessa maneira, a classe fundamental dirigiria a sociedade política pelo consenso, tendo em vista que é assistido pela sociedade civil e, assim, serena o papel da sociedade política. Gramsci conceitua

\footnotetext{
${ }^{25}$ AUGELLI, Enrico; MURPHY, Graig N. Augelli. Gramsci and international relations: a general perspective and example from recent US policy towards the third world. In: GILL, Stephen. Gramsci, historical materalism and international relations. Cambrigde: Cambrigde University Press, 1993. p. 128-129.

${ }^{26}$ AUGELLI, Enrico; MURPHY, Graig N. Augelli. Gramsci and international relations: a general perspective and example from recent US policy towards the third world. In: GILL, Stephen. Gramsci, historical materalism and international relations. Cambrigde: Cambrigde University Press, 1993. p. 128-129.

${ }^{27}$ GRIFFITHS, Martin. 50 grandes estrategistas das relações internacionais. São Paulo: Contexto, 2004. p. 174.
} 
esse processo supramencionado como democracia. Em contrapartida, a ditadura e a dominação são, respectivamente, as situações em que um grupo social não é hegemônico e domina a sociedade somente pela coerção, ou quando é hegemônico, mas não é ético, e movimenta-se pela fraude e pelo engano.

A análise direciona o entendimento que o fenômeno da superestrutura é relevante. Enquanto a estrutura pode ser os reflexos das relações de produção de base econômica, as dinâmicas da superestrutura definem o quanto a sociedade é capaz de aceitar mudanças. Gramsci usa o termo "bloco histórico" para reforçar que a estrutura e a superestrutura em conjunto formam uma ordem. Não é a superestrutura que determinará a ordem, muito menos a estrutura sozinha, mas o conjunto, o processo de relações entre os dois. ${ }^{28}$ Bloco histórico é “a unidade entre natureza e o espírito (estrutura e superestrutura), unidade dos contrários e dos distintos." 29

Gramsci parece dar ênfase à estrutura que reflete na superestrutura, mas ao contrário disso, na verdade refere-se a uma dialética entre estrutura e superestrutura. A divisão entre base e estrutura é meramente metodológica. Ele declara que o pensamento econômico pertence à sociedade civil, e que os Estados devem interferir na regulamentação econômica. Dessa forma, deve estar claro que a laissez faire é também uma forma de regulamentação estatal mantida por legislação e força coercitiva. Bloco histórico é um conceito totalizador, uma situação histórica determinada, configurações da produção, forças ideológicas e institucionais. O bloco histórico de hoje pode ser representado pelo pós-modernismo. ${ }^{30}$

A base de qualquer hegemonia está em um bloco histórico sob direção de uma classe que é dirigente ou dominante naquele tempo. Isso deve ser considerado tanto em nível nacional como internacional, pois a compreensão de seu papel histórico internacional permite o conhecimento de sua estratégia nacional. A hegemonia não é ligada pelos laços de classes sociais, mas pela utilização de um bloco ideológico, criado pelos intelectuais do grupo dirigente e formado por um laço de

${ }^{28}$ HOBDEN, Stephen; JONES, Richard Wyn. Marxist theories of international relations. In: BAYLIS, John; SMITH, Steve. The globalization of world politics. New York: Oxford Press, 2006. p. 236.

${ }^{29}$ GRAMSCI, Antônio. Cadernos do cárcere: Maquiavel. notas sobre o Estado e a Política. Rio de Janeiro: Civilização Brasileira, 2000. p. 26.

${ }^{30}$ CUTLER, Claire A. Gramsci, law, and the culture of global capitalism. Critical Review of International Social and Political Philosophy, [S.l.], v. 8, n. 4, p. 534, 2005. 
ordem psicológica e de solidariedade. Outro processo importante é a anulação dos intelectuais das outras classes pelo "transformismo" - processo de agregar e absorver chefes dos grupos auxiliares e classes subalternas para agregá-los à sua classe política ou levar em contas os interesses dos dominantes. ${ }^{31}$

Analisando-se a Revolução Bolchevista, Gramsci esquadrinhou um aprendizado sobre quais aspectos dessa poderiam ser aplicados na tentativa de uma revolução na Europa Ocidental. Suas conclusões demonstraram haver diferenças circunstanciais entre os Estados europeus, ditos ocidentais, e a Rússia, como uma estrutura oriental. O autor examinou que "no Oriente, o Estado era tudo, a sociedade civil era primitiva e gelatinosa; no Ocidente, entre Estado e sociedade civil havia uma justa relação e quando se dava um abalo do Estado, percebia-se imediatamente uma robusta estrutura da sociedade civil." ${ }^{32}$

Essa distinção entre "Oriente" e "Ocidente" foi uma tentativa de elucidar porque o modelo de assalto ao Estado feito na Rússia fracassara nos países capitalistas ocidentais. Dessa metáfora, Gramsci extraiu o conceito de "guerra de movimento" e "guerra de posição". Examinou que quando existe uma justa relação entre o Estado e a sociedade civil, o método de tomada do poder pela força, "guerra de movimento", não é eficaz, pois a hegemonia burguesa, concebida dentro da sociedade civil, fazia com que esta resistisse à vanguarda revolucionária. Porém, a "guerra de posição", ou seja, uma estratégia lenta de infiltração de agentes modificadores nas fundações estruturais para a construção de um novo Estado, ao invés, da guerra de movimento, seria o ideal.

"Guerra de posição" é definida como uma contra-hegemonia dentro de uma hegemonia pré-estabelecida. Ao invés do "reformismo", esse procedimento deve resistir às pressões e aos ganhos parciais dentro do sistema burguês que levem ao retrocesso da revolução.

Consequentemente, a tarefa do questionamento crítico das Relações Internacionais é demonstrar existir uma verdadeira consciência capaz de baixar o véu de ignorância do povo, revelar relações de forças sociais e materiais que

\footnotetext{
${ }^{31}$ PORTELLI, Hugues. Gramsci e o bloco histórico. São Paulo: Paz e Terra, 1990.

${ }^{32}$ COUTINHO, Carlos Nelson. As categorias de Gramsci e a realidade brasileira. In: COUTINHO, Carlos Nelson; NOGUEIRA, Marco Aurélio (Org.). Gramsci e a América Latina. São Paulo: Paz e Terra, 1993. p. 117.
} 
possibilitam valores específicos de certos grupos políticos prevalecerem nas relações sociais.

Existem diferenças entre as abordagens tradicionais e a abordagem neogramsciana sobre a conceituação de Hegemonia. Enquanto a abordagem da Escola Realista, por exemplo, foca-se principalmente no poder militar, força física, para determinar o Estado dominante, mais forte ou Hegemon; para abordagem neogramsciana de Cox, um Estado pode dominar os outros, sem precisar utilizar-se da força.

Para Gramsci, a hegemonia é fruto da ação de uma parte do grupo social sobre o grupo inteiro. ${ }^{33} \mathrm{Um}$ indicador da hegemonia seria uma ontologia ${ }^{34}$ que tende a subordinar e absorver todas as classes sociais. Um único entendimento intersubjetivo que exclui os demais e aparenta ser universal. ${ }^{35}$

Cox define hegemonia como "uma estrutura de valores e entendimentos sobre a natureza da ordem que permeia todo um sistema de entidades estatais ou não estatais.” A noção ordem política hegemônica implica que esses valores e entendimentos sejam incontestados e aceitos passivamente. Essa passividade baseia-se em uma combinação de coerção e consentimento exercidos em uma estrutura de poder. ${ }^{36}$ A hegemonia é o suficiente para garantir a padronização do comportamento. ${ }^{37}$

Por sua vez, Gramsci inspira-se no conceito de hegemonia de Lênin. Esse autor desenvolveu um arcabouço teórico para a orientação na direção das massas cujo fim é derrubar os demais sistemas e impor a ditadura do proletariado. Não obstante, Gramsci dá um sentido mais amplo à hegemonia, o da direção cultural, intelectual e moral. Esse conceito empregado por Gramsci, de direção pelo con-

${ }^{33}$ PORTELLI, Hugues. Gramsci e o bloco histórico. Rio de Janeiro: Paz e Terra, 1990. p. 63.

${ }^{34}$ Ontologia é a configuração da intersubjetividade. Ela nos indica o que é relevante em certo mundo, quais são as estruturas básicas e relacionamentos chave.

${ }^{35}$ COX, Robert W. Critical political economy. In: HETTNE, Björn (Ed.) International political economy: understanding global disorder. Halifax: Fernwood, 1995. p. 43.

${ }^{36}$ COX, Robert W. Rumo a uma concepção pós-hegemônica de ordem mundial: reflexões sobre a relevância de Ibn Kaldun. In: ROSENAU, James N; CZEMPIEL, Ernst-Otto. Governança sem governo: ordem e transformação na política mundial. Brasília: UnB, 2000. p. 193.

${ }^{37}$ COX, Robert W. Gramsci, hegemony and international relations: an essay in method. In: GILL, Stephen. Gramsci, historical materalism and international relations. Cambrigde: Cambrigde University Press, 1993. p. 50. 
senso ao invés da força, remete-se às metáforas de Maquiavel sobre o centauro ou sobre a raposa e o leão:

Necessitando, pois, o príncipe saber usar bem o animal, deve tirar deles as qualidades da raposa e do leão, pois o leão não se defende de armadilhas, nem a raposa dos lobos. Assim, é preciso ser raposa para suspeitar a armadilha e leão para espavorir o lobo. Aquele que se limita a ser leão ignora a arte de governar. ${ }^{38}$

Por um lado, a força só deve ser aplicada em casos específicos, quando o príncipe (e modernamente o partido) não consegue exercer sua vontade por outros meios. Em nossos dias, força corresponde à esfera pública, sociedade política em termos gramscianos, e ao Estado em termos realistas. $\mathrm{O}$ consentimento, por outro lado, corresponde à esfera privada, ou à sociedade civil.

A hegemonia, exercida por grupos dominantes que detêm o controle do Estado e o governo jurídico, tem por finalidade a produção do consentimento pela sociedade civil e a dominação da sociedade política. Além do mais, "os valores morais, políticos e culturais do grupo dominante são dissipados por meio das instituições da sociedade civil, obtendo o status de significados intersubjetivos compartilhados, daí a noção de consentimento."39

Gramsci entendeu que o terreno de luta reside na sociedade civil. Por meio da conquista da sociedade civil é que um grupo torna-se hegemônico e a conquista da sociedade política coroa esse fenômeno. ${ }^{40}$

Tratando-se de hegemonia, o trabalho de Cox deve muito a Gramsci que se voltava ao espaço doméstico da política italiana a fim de vislumbrar o cenário internacional. Para Gramsci não há dúvida que as relações internacionais seguem as relações sociais fundamentais: assim como as relações dentro dos Estados podem ser traçadas pelos movimentos sociais, a política internacional ou ordem mundial, descritas como mudanças na balança geopolítica e na estratégia militar, também refletem mudanças fundamentais nas relações sociais. No entanto, para Gramsci, o

\footnotetext{
${ }^{38}$ MAQUIAVEL, Nicolau. O príncipe. São Paulo: Germape, 2003. p. 110-111.

${ }^{39}$ SILVA, Marco Antonio de Menesses. Teoria crítica em relações internacionais. [versão não publicada]

${ }^{40}$ PORTELLI, Hugues. Gramsci e o bloco histórico. Rio de Janeiro: Paz e Terra, 1990. p. 68.
} 
Estado é a entidade fundamental das relações internacionais, isto é, o local onde o conflito social acontece e onde as hegemonias são construídas. ${ }^{41}$

Nesse contexto, Cox nota que uma ordem hegemônica internacional é baseada em dois níveis. Primeiro, no internacional, onde há, provavelmente, um Estado dominante materialmente, ainda que por si essa dominância não baste para criar uma hegemonia no cenário internacional. O segundo nível é o doméstico que depende da obtenção pelo Estado(s) dominante(s) do respaldo das camadas sociais dominantes dos demais Estados. Em outras palavras, a hegemonia internacionalmente é mantida pelo sucesso das práticas sociais das elites dominantes e da influência que elas exercem no restante da sociedade global. Essa prática, descrita como revolução passiva, é que legitima e apoia a base de uma hegemonia. ${ }^{42}$ Além disso, Cox ainda inclui a questão econômica para formação da hegemonia:

Hegemonia no nível internacional não é pois meramente uma ordem entre Estados. É uma ordem dentro da economia com um modo de produção dominante que penetra em todos os países e se liga a outros modos de produção. Também é um complexo de relações sociais conectadas a classes sociais de diferentes países. Hegemonia mundial é descritível como uma estrutura, uma estrutura econômica, e uma política; e não pode ser simplesmente uma dessas coisas, mas deve ser todas as três. Hegemonia mundial, ademais, é expressa em normas, instituições e mecanismos universais que estabelecem regras gerais de comportamento para os Estados e para aquelas forças da sociedade civil que atuam através das fronteiras nacionais - regras que dão suporte ao modo de produção dominante. ${ }^{43}$

Para se instituir uma hegemonia mundial ao contrário do que os realistas afirmam, a dominância não é o suficiente. Gramsci tinha convicção que a cultura ocidental seria hegemônica sobre toda a cultura mundial. Isto, porque a cultura

${ }^{41}$ COX, Robert W. Gramsci, hegemony and international relations: an essay in method. In: GILL, Stephen. Gramsci, historical materalism and international relations. Cambrigde: Cambrigde University Press, 1993. p. 58.

${ }^{42}$ COX, Robert W. Rumo a uma concepção pós-hegemônica de ordem mundial: reflexões sobre a relevância de Ibn Kaldun. In: ROSENAU, James N; CZEMPIEL, Ernst-Otto. Governança sem governo: ordem e transformação na política mundial. Brasília: UnB, 2000. p. 194.

${ }^{43}$ COX, Robert W. Gramsci, hegemony and international relations: an essay in method. In: GILL, Stephen. Gramsci, historical materalism and international relations. Cambrigde: Cambrigde University Press, 1993. p. 61-62. 
europeia é a única com características de assimilação universal, iniciando pelo conceito de mercado global. ${ }^{44}$

Uma hegemonia mundial tem seu início na expansão da hegemonia das classes dominantes nacionais para o restante do mundo. $\mathrm{O}$ conceito de uma ordem mundial não se resume às relações interestatais, mas incorpora a concepção de uma sociedade civil global. ${ }^{45}$ Para se modificar uma ordem mundial é preciso voltar-se às sociedades nacionais. A porta para se repensar as relações internacionais está na análise da figura Estado/sociedade civil. A transformação emerge à medida que a hegemonia antiga é contrariada por iniciativas contra-hegemônicas que possibilitam um novo bloco histórico. ${ }^{46}$

Cox chama de contra-hegemônicas as forças que minam a hegemonia. Essas forças que geram transformações podem ser Estados, coalizões de países subdesenvolvidos que afrontam a dominação das nações centrais ou atores não governamentais. Apesar de essas forças agirem internacionalmente, a fonte desses movimentos pode ser somente doméstica. ${ }^{47}$

As estruturas são instituídas socialmente e tornam-se parte do mundo real em virtude da existência da intersubjetividade dos grupos relevantes. Um exame para se entender o processo de mudança histórica precisa focalizar-se no conjunto de ideias que as pessoas têm sobre o mundo e os problemas práticos que as desafiam. ${ }^{48}$

Para a dialética histórica de Cox, apesar de as estruturas serem criadas pelos elementos de coerência, inevitavelmente também existem dentro delas contradi-

\footnotetext{
${ }^{44}$ JARDIM, Tarciso Dal Maso. Gramsci, teoria ampliada do estado e as relações internacionais. Revista Universitas Relações Internacionais, Brasília, n.1, p. 20, jul./dez. 2002.

${ }^{45}$ COX, Robert W. Gramsci, hegemony and international relations: an essay in method. In: GILL, Stephen. Gramsci, historical materalism and international relations. Cambrigde: Cambrigde University Press, 1993. p. 61.

${ }^{46}$ De forma simplificada, um bloco histórico é uma situação histórica determinada.

${ }^{47}$ DEVETAK, Richard. Critical theory. In: BURCHILL, Scott; LINKLATER, Andrew. Theories of international relations. New York: St. Martin's Press, 1995. p. 160.

${ }^{48}$ COX, Robert W. Rumo a uma concepção pós-hegemônica de ordem mundial: reflexões sobre a relevância de Ibn Kaldun. In: ROSENAU, James N; CZEMPIEL, Ernst-Otto. Governança sem governo: ordem e transformação na política mundial. Brasília: UnB, 2000. p. 191-192.
} 
ções ou conflitos. ${ }^{49}$ Essas contradições, embora restringidas pela estrutura prevalecente, são o ponto de partida para transformação mediante a ação, na medida em que a mudança histórica é consequência da atividade humana. Para se alcançar uma mudança no mundo objetivo é, portanto, importante compreender que o processo de transformação histórico é feito pela reconstrução da intersubjetividade. ${ }^{50}$

Onde há ideias sobre o mundo real incompatíveis com a necessidade de se solucionar um determinado problema no mundo, detecta-se a inadequação das estruturas fundadas sobre visão intersubjetiva e, consequentemente, busca-se uma reestruturação ou nova estrutura capaz de solucioná-los.

\section{Hegemonia e Internacionalização do Estado: Pax Britannica , Pax Americanca, Brasil e Globalização}

Utilizando-se do pensamento de Fiori ${ }^{11}$ existe uma "armação" que permite momentos de paz e prosperidade econômica entre as grandes potências no cenário internacional. Nesses momentos se pode falar em hegemonia desde que presente a "negarquia” composta por um conflito central permanente entre potências por trás do poder hegemônico que também serve de eixo organizador de todo o sistema e impede o uso unilateral e abusivo da força pelos mais poderosos. Em outras palavras, organização do "equilíbrio de poder", exclusivamente nesses períodos em que existiu uma hegemonia mundial. Sendo assim, para o autor, dois momentos históricos entre 1870-1900 e 19451973 são de essencial importância por serem representativos históricos daquilo que se entende como períodos hegemônicos, nos quais um Estado era condutor das relações internacionais. São eles o período da pax britannica e da pax americana. ${ }^{52}$

${ }^{49}$ COX, Robert W. Critical political economy. In: HETTNE, Björn (Ed.) International political economy: understanding global disorder. Halifax: Fernwood, 1995. p. 35.

${ }^{50}$ COX, Robert W. Rumo a uma concepção pós-hegemônica de ordem mundial: reflexões sobre a relevância de Ibn Kaldun. In: ROSENAU, James N; CZEMPIEL, Ernst-Otto. Governança sem governo: ordem e transformação na política mundial. Brasília: UnB, 2000. p. 191.

${ }^{51}$ FIORI, José Luís. O poder americano. Petrópolis: Vozes, 2004. p. 53-54.

${ }^{52}$ Nossa análise não é cronologicamente idêntica aos anos apontados por Fiori, porém iremos tratar de períodos históricos de forma mais ampla em termos de pax britânica e pax americana. Do nosso ponto de vista, o período 1815-1870 marcou-se pelo poderio saxão muito mais do que entre 1870-1900, quando houve claro questionamento do poder britânico e maior necessidade ou escolha de emprego da força. 
Ademais, supramencionado o modelo conceitual de Cox e Gramsci, sabendo que hegemonia é mais que dominação e que se trata, desse modo, da conjunção das forcas materiais, imagens coletivas prevalecentes e instituições que administram uma dada ordem com aparente universalidade, é interessante explorar o processo de estabelecimento de hegemonias (especificamente a britânica e a americana) conhecidas internacionalmente, para compreensão das relações a serem entendidas hoje.

A pax britannica do séc. XIX será abordada primeiramente, pois foi o primeiro modelo hegemônico capaz de internacionalizar as periferias e integrá-las ao capitalismo global. Depois será tratada a pax americana, pois, mesmo com divergências, ainda é essa a expressão hegemônica que mais afeta nossa realidade atual.

O período de hegemonia britânica foi aquele no qual se consolidaram a experiência das regras e os conceitos europeus como os outros sistemas de monopólio do poder. Um sistema único global de relações internacionais foi implementado visando à expansão da sociedade internacional europeia. Os fundamentos dessa ordem eram fruto da Revolução Francesa, do Império Napoleônico e da Revolução Industrial que forneceram respectivamente a base política/ética e econômica do capitalismo europeu ${ }^{53}$. As potências do velho continente reunidas no Congresso de Viena (O Concerto Europeu: Grã-Bretanha, Rússia, Áustria, Prússia e mais tarde, França) edificaram uma interação econômica, política e estratégica fixada por regras, instituições e valores comuns, que serviu de limite para o condicionamento das ações dos Estados. Princípios, práticas e cultura comum lhes deram uma unidade orgânica. Uma sociedade internacional europeia, de emaranhadas interações entre as comunidades e os Estados segundo valores e regras específicas ao ponto de se tornar um sistema planetário. As relações internacionais eram dominadas pela sociedade europeia que usava da expansão e dominação dos demais atores. Esse entrelaçamento de relações, embora também limitasse a liberdade das potências, criava uma sociedade que o favorecia e mostrou um efetivo meio de dominação. Os europeus eram supremos nas relações com os novos Estados da América, África e Oceania; e ainda chegaram a impor sua visão sobre os muçulmanos e asiáticos.

\footnotetext{
${ }^{53}$ Fiori ainda aponta a formalização do mercando interno, união territorial e aduaneira, mediante financiamento da dívida pública dos reis pelos bancos nacionais, como um elemento básico que determinou o capitalismo.
} 
O restante do mundo era obrigado a copiar o modelo europeu, excluindo-se daqueles o poder de modificar regras e instituições. Essa faculdade era do Concerto Europeu que administrava a sociedade internacional sob seu controle hegemônico político. Os demais eram recomendados a adequar suas estruturas internas às instituições representativas, ao comércio liberal e ao Direito Internacional. De fato, a expansão europeia teve dominação estratégica, exploração econômica e imperialismo cultural. Sua diplomacia de conferências era, na verdade, a representação das grandes potências segundo a liberdade de seus próprios interesses..$^{54}$

Por sua vez, o período enfoca a proeminência britânica no mundo. Essa conseguia preponderar suas concepções sobre as outras potências, era industrialmente mais capaz devido a ser berço tecnológico, militarmente mais hábil e detinha capital e territórios. E, por fim, não admitia uma nova hegemonia ao estilo napoleônico. Queria a transformação do sistema composto de múltiplas independências e um hegemônico para um sistema de independências moderadas e um concerto entre grandes potências e, portanto, exigiu a integração da França para manter-se o equilíbrio da balança de poder. Essa hegemonia em concerto era flexível aos interesses da Grã-Bretanha visto que adicionou à ordem criada os interesses de sua expansão capitalista e o cunho das classes burguesas. ${ }^{55}$

O liberalismo da classe média inglesa, e também a francesa, denotava eficiência governamental que promovesse o comércio e indústria, sistema legislativo representativo dos burgueses, uma política externa de paz e de livre comércio, crença no individualismo e nas doutrinas econômicas clássicas. ${ }^{56}$

Em verdade, segundo o pensamento de Smith, o poder econômico inglês dispensava o uso de monopólios coloniais e conquistas de territórios; sua superioridade econômica acentuada pela Revolução Industrial e a força do seu capital

\footnotetext{
${ }^{54}$ CERVO, Amado Luiz. Hegemonia coletiva e equilíbrio: a construção do mundo liberal (1815-1871). SARAIVA, José Flávio Sombra. (Org.) Relações internacionais dois séculos de história: entre a preponderância européia e a emergência americana (1815-1947). Brasília: IBRI, 2001. v. 1. p. 61-71.

${ }^{55}$ CERVO, Amado Luiz. Hegemonia coletiva e equilíbrio: a construção do mundo liberal (1815-1871). In: SARAIVA, José Flávio Sombra. (Org.) Relações internacionais dois séculos de história: entre a preponderância européia e a emergência americana (1815-1947). Brasília: IBRI, 2001. v. 1. p.71-72.

${ }^{56}$ BURNS, Edward Mcnall; LERNER, Robert E; MEACHAM, Standish. História da civilização ocidental. São Paulo: Globo, 2005. v. 2. p. 551.
} 
financeiro eram suficientes para obrigar a especialização econômica das demais nações. ${ }^{57} ;{ }^{58}$

Com a abertura do restante do mundo ao comércio europeu, os governos tiveram que se endividar na praça inglesa e francesa para cobrir os recursos aduaneiros perdidos. Em momentos de retração desse crédito ou/e da contração da demanda por produtos primários, necessariamente havia problemas de balança de pagamentos e déficit públicos que os obrigavam a renegociar dívidas, gerando, no caso da América Latina, socialização das perdas financeiras. E no caso asiático, quando não renegociadas segundo os padrões europeus, acabaram justificando a intervenção e dominação política.

Sendo assim, a Grã-Bretanha atingiu o auge da sua hegemonia política, econômica e militar no mundo e impôs a sua versão do capitalismo liberal por quase todo o planeta. Essa supremacia foi baseada: 1) no poder naval (que permitiu a proteção do território britânico de invasões, o uso do seu poderio militar contra países periféricos, à utilização da balança artificial de poder continental a seu favor); 2) no liberalismo econômico e no poder industrial (mercado livre, padrãoouro, movimento de capitais); 3) na ideologia universalista baseado na harmonia de interesses e prestígio cultural. Todos esses fatores entretecidos pelo Direito Internacional e garantidos pela supremacia militar..$^{59}$

O Concerto como um todo se adequou aos interesses capitalistas. A GrãBretanha, centro do capitalismo, permitiu a abertura dos mercados mundiais às produções industriais do continente europeu, favorecendo a si mesma e ao pentagrama do concerto como um todo. Como exemplo, não houve qualquer regime monetário pactuado entre as nações para estabelecer um sistema monetário internacional baseado na libra, ao invés disso, era um sistema de adesão progressivo dos países periféricos e centrais, obrigados a utilizarem essa moeda nas suas investidas comerciais ou imperiais, que, conforme Fiori, já era "território econômico inglês" 60

${ }^{57}$ FIORI, José Luís. O poder americano. Petrópolis: Vozes, 2004. p. 47-48

${ }^{58}$ Já o pensamento posterior de Benjamin Disraeli e Cecil Rhodes, segunda metade do séc. XIX, preconizavam a retomada do colonialismo.

${ }^{59}$ COX, Robert W. Social forces, states and world orders: beyond international relations theory. In: COX, Robert; SINCLAIR, Timothy. Approaches to world order. Cambridge: Cambridge University Press, 1996. p. 103.

${ }^{60}$ FIORI, José Luís. O poder americano. Petrópolis: Vozes, 2004. p. 54. 
Os historiadores deixam claro ao apontarem que o caso brasileiro de inserção nas relações internacionais é um exemplo clássico da hegemonia inglesa. A "aliança inglesa" com Portugal, uma ex-potência vinculada aos saxões, explica a nossa herança, entrada direta no sistema internacional europeu, principalmente, nossa dependência econômica e nosso arcabouço jurídico-político ${ }^{61}$

Nesse sentido, a famosa abertura dos portos às nações amigas de D. João consistia na vontade de Canning em assegurar privilégios ingleses e resultou no gênero inglês de tratados desiguais que iriam subjugar as áreas periféricas aos interesses do capitalismo. Já o Tratado de Comércio e Navegação de 1810 denotava a ausência de reciprocidade e equidade, primando pela justiça privada aos ingleses no Brasil, liberdade de culto e livre imigração dos ingleses, rebaixava a tarifa para produtos ingleses e limitava a exportação de produtos nacionais. Assinaram-se tratados similares nos países da América Latina, ligando-os ao liberalismo comercial, tornando-os parte do jogo internacional como agentes dependentes ${ }^{62}$

Crueldade é imaginar uma ingenuidade de ambas as partes nesse processo, e muito pior um comutado entre elites. A natureza das relações não era imposta somente com o poder do canhão, mas pelo consentimento bilateral, de caráter econômico, que inaugurava uma divisão internacional do trabalho. Os burgueses europeus só tinham a lucrar com o processo, mas os grupos sociais hegemônicos na América Latina, apesar de contarem com poucas divergências, apoiavam a retórica liberal europeia, enxergavam nesse processo a possibilidade de exportação dos produtos domésticos, a ampliação do seu poder de compra, o consumo dos produtos importados, e, consequentemente, o poder político. Os maléficos latinos poderiam ser vistos futuramente na disparidade dos termos de troca, consolidação do sistema econômico nacional voltado para o mercado exterior, acesso restrito da população à renda e à limitação do comércio interno,

${ }^{61}$ CERVO, Amado Luiz; BUENO, Clodoaldo. História da política exterior do Brasil. Brasília: UnB, 2002. p. 17.

${ }^{62}$ CERVO, Amado Luiz. Hegemonia coletiva e equilíbrio: a construção do mundo liberal (1815-1871). In: SARAIVA, José Flávio Sombra (Org.). Relações internacionais dois séculos de história: entre a preponderância européia e a emergência americana (1815-1947). Brasília: IBRI, 2001. v. 1.p. 84. 
sem contar com a manutenção da escravatura naquele momento. ${ }^{63}$ Outro cunho da aproximação latino-americana com a Grã-Bretanha era a disposição dessa potência em impedir a reconquista europeia das ex-colônias, contudo as vantagens econômicas eram o mais persuasivo para elites locais, principalmente após a independência.

Mesmo que, no caso brasileiro, as concessões de D. Pedro tenham provocado sua queda em 1831, de fato, de 1810 até 1826, houve pouco manifesto contrário, tendo em vista que após a independência, em 1822, demorou-se quatro anos para a criação de um Parlamento. Segundo esse órgão, o sistema de tratados determinou um reconhecimento da independência que sacrificou direitos nacionais, soberania (os tratados legislavam sobre assuntos internos como fiscal e o criminal) e impôs o liberalismo ao Brasil. ${ }^{64}$

Na realidade, o Parlamento não se opôs ao liberalismo, mas de certa forma reconheceu, em certo momento, que os fatos promoviam a supressão da autonomia industrial em favor de uma inconsciente ao setor agrário. O que consequentemente sobretaxou, em termos de ganhos relativos, a soberania e a autonomia brasileira na cena internacional.

Historiadores da Escola de Brasília das Relações Internacionais apontam que os Teóricos da Dependência, escola de natureza marxista, dão ênfase demais a um conluio entre grupos hegemônicos das nações industrializadas e das agroexportadoras. Para aqueles historiadores, o Estado brasileiro cedeu aos interesses externos, de forma não ditada pelo grupo hegemônico interno, até mesmo o Parlamento se posicionou contra essa inserção. Houve, portanto, um erro decisório na busca de reconhecimento internacional. ${ }^{65}$

Possivelmente tal erro decisório existiu. Mas é importante para o conhecimento histórico saber o porquê desse erro. Primeiro, é possível que a imperícia

${ }^{63}$ CERVO, Amado Luiz. Hegemonia coletiva e equilíbrio: a construção do mundo liberal (1815-1871). In: SARAIVA, José Flávio Sombra (Org.). Relações internacionais dois séculos de história: entre a preponderância européia e a emergência americana (1815-1947). Brasília: IBRI, 2001. v. 1.p. 85.

${ }^{64}$ CERVO, Amado Luiz; BUENO, Clodoaldo. História da política exterior do Brasil. Brasília: UnB, 2002. p. 48.

${ }^{65}$ CERVO, Amado Luiz; BUENO, Clodoaldo. História da política exterior do Brasil. Brasília: UnB, 2002. p. 49-50. 
política dos atores nacionais em discernir os efeitos desse processo seja algo historicamente relevante. Porém, é também factual que havia uma vontade política nacional de participação nesse processo. O erro não pode ser atribuído exclusivamente à imprudência, à negligência ou à imperícia dos brasileiros. Não havia um simples erro sobre a realidade dos fatos envolvendo as relações internacionais. Foi um erro marcado por traços ideológicos que comprometeram o pragmatismo. Foi um erro de percepção provocado por fatores nacionais e internacionais. Notese que as condições estruturais fomentaram o erro sobre a percepção do que era interesse nacional em longo prazo. A admiração e respeito pelo poderio militar inglês, a visão do liberalismo pelos brasileiros, a apontada necessidade da integração econômica ao capitalismo, a procura de inserção na política internacional, a busca ao prestígio europeu e a incorporação nos cálculos políticos das pressões sociais de órgãos de classes sobre a política externa da Grã-Bretanha e do Brasil, dentre outros fatores, contribuíram para a consolidação de uma vontade nacional de aceitação das regras do jogo. Foi um erro causal e jamais um erro mecânico. Ou seja, um erro que teve como fator determinante a hegemonia cultural, militar, econômica e intelectual dos ingleses.

Denominador comum entre ambas as escolas é que essa internacionalização do Estado brasileiro cooperou com os interesses da sociedade europeia. Foi fruto de um processo hegemônico feito por valores, princípios, interesses, normas jurídicas, repetições, institucionalismo brando e congruente, sucumbência ou adesão ao processo presente.

No Brasil, o paradigma que expressou a conformidade com o plano europeu foi a cosmovisão liberal conservadora, uma visão política de prestígio, buscando ser aceito na Europa, garantir uma aproximação cordial com as superpotências, garantir crédito e exportar produtos agrícolas que germinaram nas instituições e práticas nacionais ajustarem-se às estruturas e dinâmicas de uma economia mundial capitalista.

Essa estrutura histórica, porém, do último quarto do séc. XIX até a segunda guerra transformou-se. O Poder britânico declinou, primeiro com o ressurgimento dos nacionalismos, passando pelo protecionismo, novo imperialismo, resultando na Liga das Nações como forma de cultivar o pensamento liberal e, por último, culminando sua bancarrota na pax americana 
A hegemonia americana ou pax americana é mais robusta que a antecedente e levaria em consideração as alianças criadas para conter a expansão soviética. Essa configuração de blocos teria como central a internacionalização do Estado, criando uma economia global segundo a qual os Estados Unidos seriam seu garantidor. Contudo, os Estados Unidos raramente precisaram intervir diretamente na esfera econômica internacional, pois as utilizações de regras econômicas internacionais promovidas pelas instituições formuladas em Bretton Woods, aliadas a empresas e ao capital americano foram suficientes para garantir o sistema de poder americano. Ou seja, a internacionalização da vontade americana baseada em instituições constituiu uma noção de "obrigação internacional"66.67

Cox apresenta três dimensões para esses processos de hegemonias culminarem na internacionalização do Estado: "um processo de formação de consenso dentro do Estado com respeito às necessidades ou exigências da economia mundial que ocorre dentro de uma estrutura ideológica comum, [...] a participação na negociação desse consenso é hierárquica, [...] as estruturas internas dos Estados são ajustadas de tal forma que cada uma pode transformar melhor o consenso global em políticas e práticas nacionais." ${ }^{38}$

Com o final da Segunda Grande Guerra extingue-se o isolacionismo americano. Com a rendição do Eixo fica clara a nova posição americana de superpotência militar e líder do capitalismo. Para regular o sistema condominial de poder os Estados Unidos utilizaram das Conferências de Teerã, Yalta, Potsdam, da Política de Contenção de George Kennan/Doutrina Truman e da criação da Organização do Tratado Norte. Já para garantir o mercado japonês, latino-americano e Euro-

${ }^{66}$ COX, Robert W. Social forces, states and world orders: beyond international relations theory. In: COX, Robert; SINCLAIR, Timothy. Approaches to world order. Cambridge: Cambridge University Press, 1996. p. 104.

${ }^{67}$ Para Cox, a pax americana pode ser dividida em três períodos: 1930-1945, momento dos Estados fechados e fortemente centralizados; 1945-1970, quando os Estados se compromissavam com o fortalecimento da economia mundial, responsabilidade frente o sistema de Breton Woods, bem-estar social e desempenho econômico: 1970- ?, pelo processo de globalização, regionalismo, reestruturação do Estados e da economia mundial, compromisso internacional/nacional com instituições transnacionais/multinacionais e redes de poder. GRIFFITHS, Martin. 50 Grandes estrategistas das relações internacionais. São Paulo: Contexto, 2004. p. 175.

${ }^{68}$ GRIFFITHS, Martin. 50 Grandes estrategistas das relações internacionais. São Paulo: Contexto, 2004. p. 175. 
pa Ocidental aos americanos, foram criados planos econômicos como Colombo, Marshall e inúmeras instituições internacionais. Isso significou a consolidação que a posição americana passou a exercer de forma ostensiva ao redor do mundo; políticas americanas de expansão e proteção dos interesses americanos foram implementadas na Casa Branca difundidas ao mundo capitalista.

$\mathrm{Na}$ época, os oligopólios internacionais dão origem às empresas multinacionais americanas que passam a investir capital na Europa, Japão, no terceiro mundo, e a expandir ainda mais sua produção. Para evitar o erro cometido na Primeira Guerra, os vencidos e ganhadores receberam um forte fluxo de investimento para a reconstrução da Europa - Plano Marshall - e do Japão - Plano Colombo.

Demonstrando assim, a poder econômico, industrial e político americano que reintegraria os derrotados na economia mundial, promoveria a reconstrução e, também, conforme um delegado russo na reunião do Conselho Econômico e Social das Nações Unidas - ECOSOC sugeriu, "promoveria a dominação da economia europeia por grupos monopolistas americanos. Seria um artifício usado pelos Estados Unidos para evitar a crise doméstica de superprodução." ${ }^{6}$

Esse processo de multinacionais é entendido como a expressão mais avançada do capitalismo, moldando as relações do trabalho segundo suas bases, rompendo de vez com a competição imperial sobre disputa de matérias primas e mercados entre empresas nacionais. Envolve, desse modo, três movimentos interligados: i) movimentos de capitais; ii) produção capitalista internacional; e iii) ações intergovernamentais. ${ }^{70}$

Movimentos de capitais internacionais procedem de investimentos empresariais diretos, estimulam as finanças internacionais e depósitos em bancos estrangeiros. Esses ativos captados no mundo passam a crescer mais do que os investimentos diretos, pois são multiplicados em outras ações financeiras e geram uma síntese entre capital nacional e estrangeiro do mercado financeiro internacional,

${ }^{69}$ MAIA, Jayme de Mariz. Economia internacional e comércio exterior. São Paulo: Atlas, 2007. p. 227.

${ }^{70}$ OLIVEIRA, Ariovaldo Umbelino de. A mundialização do capitalismo e a geopolítica no fim do século XX. In: ROSS, Jurandyr L. Sanches (Org.). Geografia do Brasil. São Paulo: USP, 2000. p. 244. 
ou seja, tornam-se investimentos criadores e geradores de capacidade produtiva. ${ }^{71}$ Não é um único mercado, mas um grupo de mercados interconectados por troca de ativos. É composto por bancos comerciais, grandes firmas, instituições financeiras não bancárias, bancos centrais ${ }^{72}$ e até paraísos fiscais.

A produção capitalista internacionalizada deriva da revolução tecnológica do período, das multinacionais, dos fluxos de capitais disponíveis e da abertura das economias nacionais. Essa produção controla a força de trabalho, mercados, fontes de matérias-primas, e substitue a antiga disputa por matéria-prima das antigas rivalidades imperiais por cooperação entre empresas estrangeiras que se associam a outras empresas, às vezes nacionais, para obtenção de matérias e mão de obra, sempre visando à eficiência. ${ }^{73}$ Essa mundialização da produção descentralizou, de certa forma, a atividade industrial e criou uma nova divisão internacional do trabalho.

Ações internacionais de governos são a base da cooperação internacional e formam o alicerce do alinhamento das políticas internas ao Direito Internacional. Apesar de parecer contrassenso, inicialmente essas ações são marcadas pelas fortes ações dos Estados, justamente para assegurar o livre comércio e capitalização. ${ }^{74}$ Para isso nasce uma gama de instituições de caráter internacional para coordenar as ações entre Estados, fato que marca uma grande diferença entre a pax britannica de institucionalismo brando e a pax americana de institucionalismo intenso.

Nesses moldes, a Organização das Nações Unidas - ONU foi criada para garantir a paz e segurança nacional, desenvolver relações entre as nações, promover os direitos humanos e ser o centro da harmonização das ações entre as nações, mesmo daquelas fora do condomínio americano. Essa organização internacional é marcada pela pluralidade de instituições internacionais que refletem tanto os de-

${ }^{71}$ OLIVEIRA, Ariovaldo Umbelino de. A mundialização do capitalismo e a geopolítica no fim do século XX. In: ROSS, Jurandyr L. Sanches (Org.). Geografia do Brasil. São Paulo: USP, 2000. p. 244.

${ }^{72}$ KRUGMAN, Paul R.; OBSTFELD, Maurice. Economia internacional: teoria e prática. São Paulo: Pearson, 2005. p. 472.

${ }^{73}$ OLIVEIRA, Ariovaldo Umbelino de. A mundialização do capitalismo e a geopolítica no fim do século XX. In: ROSS, Jurandyr L. Sanches (Org.). Geografia do Brasil. São Paulo: USP, 2000. p. 244.

${ }^{74}$ OLIVEIRA, Ariovaldo Umbelino de. A mundialização do capitalismo e a geopolítica no fim do século XX. In: ROSS, Jurandyr L. Sanches (Org.). Geografia do Brasil. São Paulo: Usp, 2000. p. 255. 
sejos das potências vencedoras (por exemplo, o direito de veto no Conselho de Segurança) como aqueles universais, ${ }^{75}$ e até mesmo os do terceiro mundo que, de certa forma, passaram a ser institucionalizados em organizações como a Conferência das Nações Unidas sobre Comércio e Desenvolvimento - UNCTAD ou a Comissão Econômica para a América Latina e Caribe - CEPAL.

O Fundo Monetário Internacional - FMI foi criado para auxiliar o sistema monetário internacional. Seus objetivos são: supervisionar o cumprimento de regras de comércio internacional, finanças (exigia, por exemplo, taxas de câmbio fixas ao dólar americano garantido em ouro pelo Federal Reserve Bank - FED) e facilitar empréstimos para nações com problemas na balança de pagamentos, mas apenas com supervisão feita sobre as políticas macroeconômicas dos devedores. ${ }^{76}$

Os recursos do Fundo são totalizados por cotas de capital integrado por cada membro; quanto maior a cota de participação, maior o peso de voto daquele país. Isso significa que os países mais ricos possuem poder de decisão no Fundo, por exemplo, os Estados Unidos, maior cotista, possuem cerca de $17 \%$ do poder de voto e o Brasil $1 \%{ }^{77}$

Segundo alguns autores, o FMI tem como meta o controle das economias capitalistas nacionais, cria uma forma de dependência gerada pelo endividamento externo que, por sua vez, funciona como pressão aos devedores para ampliarem suas políticas de exportação e abrirem suas fronteiras. ${ }^{78}$

Porém, é necessário devida cautela nesses tipos de conclusões para não banalizar o que pode ser visto como formas hegemônicas de poder como mero discurso anti-imperialista, fanático e propagandista.

Outra crítica feita hoje é que os temas monetários, a partir de 1975, passaram a ser determinado dentro do G7, reduzindo as chances dos demais países em

75 TAYLOR, Paul; CURTIS, Devon. The United Nations. In: BAYLIS, John; SMITH, Steve. The globalization of world politics. New York: Oxford Press, 2006. p. 406.

${ }^{76}$ KRUGMAN, Paul R.; OBSTFELD, Maurice. Economia internacional: teoria e prática. São Paulo: Pearson, 2005. p. 408-409.

${ }^{77}$ FUNDO MONETÁRIO INTERNACIONAL. Disponível em: <http://www.imf. org/external/np/sec/ memdir/members.htm>. Acesso em: 15 jul. 2009.

${ }^{78}$ OLIVEIRA, Ariovaldo Umbelino de. A mundialização do capitalismo e a geopolítica no fim do século XX. In: ROSS, Jurandyr L. Sanches (Org.). Geografia do Brasil. São Paulo: USP, 2000. p. 254. 
utilizarem do FMI como fórum mais democrático de tratamento do tema. Dessa visão, parece nascer a tentativa do governo Lula ampliar o G7 para o G20.

O Banco Internacional de Reconstrução e Desenvolvimento (ou Banco mundial - BIRD) e afiliadas foram criados para facilitar o investimento e a reconstrução da Europa. Mas hoje, sua principal função é ajudar o desenvolvimento em longo prazo das nações subdesenvolvidas. EUA, Reino Unido, Alemanha, França e Japão controlam $47 \%$ do poder de decisão do Banco. ${ }^{79} \mathrm{Na}$ década de 50 , financiou a reconstrução; nos anos 60, ajudou o terceiro mundo em projetos de infraestrutura e logística; nos anos 70, o desenvolvimento da agricultura e de programas sociais; e nos anos 80-90, reestruturação para resolver o problema das dívidas externas e estimular a modernização ${ }^{80}$

O FMI e o BIRD são um veículo de assistência direta efetivada somente depois que os futuros devedores garantirem que vão se adequar às normas estabelecidas. Essas organizações têm mecanismos para supervisionar se as normas internacionais são cumpridas. Articulam ações supranacionais para que os países adotem, individualmente, políticas e ações que os conforme com a realidade da comunidade financeira internacional. Cumprem a função de articular os interesses do capital monopolista multinacional e das elites nacionais, numa espécie de 'grande governo econômico-financeiro internacional' do mundo capitalista. Garantem, dessa forma, a gestão mundial da economia capitalista mundializada." ${ }^{1}$

Para desenvolver o comércio internacional, foi criado o Acordo Geral de Livre Comércio - GATT, mais tarde complementado pela Organização Mundial do Comércio -OMC. O GATT era um simples acordo que visava promover o comércio multilateral, enquanto a OMC é uma instituição internacional mais ampla, envolvendo comércio, serviços e direitos de propriedade intelectual. ${ }^{82}$ Es-

\footnotetext{
${ }^{79}$ OLIVEIRA, Ariovaldo Umbelino de. A mundialização do capitalismo e a geopolítica no fim do século XX. In: ROSS, Jurandyr L. Sanches (Org.). Geografia do Brasil. São Paulo: USP, 2000. p. 254.

${ }^{80}$ MAIA, Jayme de Mariz. Economia internacional e comércio exterior. São Paulo: Atlas, 2007. p. 230.

${ }^{81}$ OLIVEIRA, Ariovaldo Umbelino de. A mundialização do capitalismo e a geopolítica no fim do século XX. In: ROSS, Jurandyr L. Sanches (Org.). Geografia do Brasil. São Paulo: USP, 2000. p. 254.

${ }^{82}$ MAIA, Jayme de Mariz. Economia internacional e comércio exterior. São Paulo: Atlas, 2007. p. 255.
} 
ses acordos visavam abolir o protecionismo mundial e integrar o mundo em um mercado global.

Com as multinacionais, movimentos de capitais, produção capitalista internacionalizada e ações internacionais de governos, um mecanismo de harmonização de políticas entre os países foi estabelecido nos anos do pós-guerra. A noção de obrigação internacional passou a ser mais profunda. Principalmente na política econômica internacional. Os Estados deixaram de ser comprometidos exclusivamente com os princípios de gerais do comércio (por exemplo, o da nação mais favorecida ou da manutenção de taxas de câmbio) e adotaram um sistema complexo com inúmeros elementos intrínsecos. Ou seja, passaram para o multilateralismo que significa comprometimento com um todo. A internacionalização do Estado deu procedência a agências, ministérios e órgãos nacionais que devem anuir às políticas internacionais para maior entrada do Estado, sociedade civil e empresas ao mercado internacional. Gerando uma dominância dos setores nacionais econômicos domésticos sobre os demais setores domésticos direcionados para o mercado interno ${ }^{83}$

Esse processo da pax americana percorreu cerca de 40 anos da História Mundial, presenciou o crescimento do poder econômico europeu e japonês, das transformações da especialização flexível pós-fordista, choques do petróleo, desvalorização do dólar e colapso do sistema de conversibilidade de Bretton Woods, terceira revolução industrial ou revolução técnica, queda do socialismo e geminou naquilo que hoje denominamos globalização.

Arrighi, dissertando sobre ciclos da economia mundial, diagnostica uma "crise terminal" da hegemonia norte-americana que teria começado nos anos 70 . Quatro seriam os sintomas associados em todas as crises que acarretam transições hegemônicas: 1) grandes expansões financeiras, sobreprodução e disputas estatais pelos capitais circulantes; 2) aumento de competição capitalista estatal; 3 ) escalada de conflitos sociais, coloniais ou civilizatórios; e 4) novas configurações de poder capazes de vencer o antigo estado hegemônico ${ }^{84}$

${ }^{83}$ COX, Robert W. Social forces, states and world orders: beyond international relations theory. In: COX, Robert; SINCLAIR, Timothy. Approaches to world order. Cambridge: Cambridge University Press, 1996. p. 109.

${ }^{84}$ ARRIGHI apud. FIORI, José Luís. O poder americano. Petrópolis: Vozes, 2004. p. 16. 
Ao contrário desse autor, Fiori argumenta que os acontecimentos, crise dos anos 70 e fim da Guerra Fria, transferiram para os Estados Unidos da América EUA a centralidade monetária, militar e financeira de forma inigualável. Não há necessariamente uma bifurcação do poder militar e do poder econômico. Ambos estão nas mãos americanas. Pelas configurações do cenário atual os Estados Unidos podem sofrer problemas, mas nada evidencia a fase terminal do sistema capitalista, nem mesmo o término da hegemonia americana. ${ }^{85}$

O mesmo argumento é trazido por Joseph Nye, em "O Paradoxo do Poder Americano", que testifica que, mesmo com o crescimento da China, Índia, Europa e Japão, os Estados Unidos ainda seriam dominantes em termos militares e econômicos por um longo período de tempo.

Mas o fato é que os mercados se internacionalizaram, podendo sim falar de uma nova força que atinge e se expande globalmente. Isso, no final, gera a concessão de poder político aos atores econômicos.

Esse processo marca o crescimento do poder econômico sobre as demais formas de poder. "Globalização é, de certa forma, o ápice do processo de internacionalização do mundo capitalista." ${ }^{86}$

O conceito é que vivemos em sociedade determinadas por processos globalmente articulados capazes de promoverem uma unificação global em tempo real. Comunicação, transportes e tecnologia permitem a existência da interdependência global. ${ }^{87}$

Outros conceitos estão ligados a ela: internacionalização, que reflete a ideia de interdependência nas ações estatais; regionalização, que concebe a noção de integração entre nações com bases territoriais ou políticas comuns; sociedade civil transnacional, arena política transfronteiriça em que cidadãos e interesses privados interagem para resolução de objetivos e formam instituições para representá-los; institucionalização, organizações com intuito de criar redes sociais de interação; redes transnacionais, for-

\footnotetext{
${ }^{85}$ FIORI, José Luís. O poder americano. Petrópolis: Vozes, 2004. p. 18.

${ }^{86}$ SANTOS, Milton. Por uma outra globalização: do pensamento único à consciência universal. Rio de Janeiro: Record, 2002. p. 23.

${ }^{87}$ CASTELLS, Manuel. Global Governance and Global Politics. Political Science \& Politics. v.38, n. 1, jan. 2005, p. 10. Disponível em: <http://www. manuelcastells. info/en/obra_02. htm> Acesso em: 1 jun. 2009.
} 
mais e informais que ligam agências nacionais (Estados) com agências estrangeiras (instituições internacionais) e seus pares para coordenação, harmonização, diálogo e efetividade de políticas comuns; desagregação do estado, tendência da máquina governamental ficar presa aos temas transnacionais e redes políticas internacionais. ${ }^{88}$

A globalização é evidente nos diferentes campos da vida: econômico, militar, legal, ecológico,, cultural. Na economia abrolha o comércio, as finanças e a produção que criam um mercado comum, processo de uma única economia capitalista. As multinacionais organizam a produção, enquanto os mercados determinam quem recebe crédito em que termos. Na esfera militar, o comércio de armas, o combate ao terrorismo, a cooperação militar e o controle de proliferação de armas nucleares demonstram uma rede global e uma ordem militar norte-americana. No Direito Internacional nota-se a expansão de normas [obrigações internacionais] de economia, direitos humanos, serviços, bens, propriedade, direito criminal, e a criação de instituições internacionais para garantir essas normas. Ambiental é a área em que lidamos com problemas ambientais que afetam o presente e o futuro da humanidade e criam-se redes para solução desses problemas, principalmente, regimes internacionais. Cultural é o complexo de harmonização da cultura popular, sua difusão ao mundo pela internet, mídia, agências de notícias, ${ }^{89}$ e pela também resistência de identidades tradicionais e de terceiro mundo que buscam a contra-hegemonia do processo aqui mesmo descrito, utilizando-se dos mesmos meios, quando não excluídos, para contrabalancearem o buscar alternativas à globalização.

A técnica, a economia e a política dão a expressão desse momento. Técnica refere-se à questão que sem a logística da comunicação e transportes nada disso aconteceria. Economia é a chave da lógica capitalista necessária para um novo mercado aberto, busca do lucro e eficiência. Política é a fonte das ideias, interesses e poderes envolvidos. Se a técnica é a base real da globalização, a política é a base normativa desse processo. Governos como o americano e o inglês são atores cruciais para o nascimento da globalização. ${ }^{90}$

\footnotetext{
${ }^{88}$ MCGREW, Anthony. Globalization and global politics. In: BAYLIS, John; SMITH, Steve. The globalization of world politics. New York: Oxford Press, 2006. p. 25.

${ }^{89}$ MCGREW, Anthony. Globalization and global politics. In: BAYLIS, John; SMITH, Steve. The globalization of world politics. New York: Oxford Press, 2006. p. 27.

${ }^{90}$ MCGREW, Anthony. Globalization and global politics. In: BAYLIS, John; SMITH, Steve. The globalization of world politics. New York: Oxford Press, 2006. p. 27.
} 
Há previsão, em Marx, que, pela necessidade de novos mercados, a burguesia invadiria o mundo e buscaria ter vínculos cosmopolitas em todos os lugares. Mas o autor não toma em conta a importância do território para o desenvolvimento capitalista. Essa segunda orientação foi proclamada por Hilferding que percebeu que o poder político era decisivo para a competitividade econômica. Buhkharin, não muito longe desse pensamento, completou essa visão afirmando que "as diferentes esferas do processo de concentração e de organização se estimulam mutuamente e fazem surgir forte tendência à transformação de toda economia nacional numa gigantesca empresa combinada sob a égide dos magnatas das finanças e do Estado capitalista: uma economia que monopoliza o mercado mundial"'

O desenvolvimento do capitalismo mundial resulta na internacionalização das relações humanas, tendo em vista seu estreito relacionamento com todos os campos da vida humana. Por outro lado, leva a tendência de estreitamento dos grupos ligados pelo capital.

Hilferding propõe que a política do capital financeiro tenha três objetivos. Primeiro, criar um território econômico; em segundo, a defesa desse território por meio de barreiras alfandegárias; em terceiro, transformar esses locais em campo de exploração para os monopólios do país. O território econômico supranacional seria quase sempre uma face do território político, como nos casos das colônias inglesas, e, quando não houvesse essa coincidência, a competição entre as grandes potências se deslocaria do campo político para o monetário. Essa competição é vencida por quem impõe sua moeda nacional, assegura barreiras não alfandegárias que proteja seus investimentos e cria um ambiente favorável para o capital financeiro na economia conquistada. ${ }^{92}$

As ações dos grandes "estados/economias nacionais" são iguais ao dos "grandes predadores privados". É impossível a existência de territórios econômicos de alianças sem o poder político. A globalização é a dilatação do movimento contínuo das grandes potências econômicas pelo mercado global. ${ }^{93}$

\footnotetext{
${ }^{91}$ HILFERDING apud FIORI, José Luís. O poder americano. Petrópolis: Vozes, 2004. p. 43.

${ }^{92}$ HILFERDING apud FIORI, José Luís. O poder americano. Petrópolis: Vozes, 2004. p. 44.

${ }^{93}$ FIORI, José Luís. O poder americano. Petrópolis: Vozes, 2004. p. 43.
} 
O Brasil não ficou imune ao capitalismo monopolista. No pós-guerra, inicialmente, o Brasil aceitou as condições do multilateralismo americano, contudo, ao se deparar como jogador de segundo plano pelos EUA, buscou implementar um modelo de inserção alternativo que oscilava entre desenvolvimento autônomo e desenvolvimento associado, mas jamais escolhendo de fato uma via terceiro mundista não alinhada. O modelo ficou conhecido como o Paradigma do Estado Desenvolvimentista, que se estende de 1930 a 1989.

Seu componente teórico era introduzir nas negociações internacionais os temas das disparidades econômicas; promover o desenvolvimento e, por consequência, industrialização brasileira; satisfação do conceito de sociedade complexa brasileira e suas necessidades; autonomia decisória nas relações internacionais para ganhos recíprocos; implementação de um projeto nacional de desenvolvimento para superar as desigualdades; movimentação para o centro das decisões; imitação do nacionalismo econômico das grandes potências; uso da política externa para cooperação, política de comércio flexível e não doutrinária; subordinação da política de segurança aos fins econômicos e negociação simultânea com os grandes vizinhos. ${ }^{94}$

Além do desenvolvimentismo mencionado, o Brasil também possuía um caráter liberal, ocidental e "democrático". O desenvolvimento teve três vertentes. Uma associada às forcas externas do capitalismo, de vínculos políticos, geográficos e econômico com o centro do sistema internacional. Entenda como Gaspar Dutra, Castelo Branco e, em fase seguinte, Fernando Collor e até Fernando Henrique Cardoso que zelaram pela aproximação com os EUA. ${ }^{95}$

A segunda vertente é a do desenvolvimentismo autônomo recomendada por Getúlio Vargas, João Goulart e Ernesto Geisel, que cobria a política de cunho econômico centralizados no poder nacional. ${ }^{96} \mathrm{~A}$ via média pode ser conhecida como o nacional-desenvolvimentismo de Juscelino Kubitschek, combinando a atividade do Estado (infraestrutura), das empresas nacionais/internacionais e do capital estrangeiro em busca da industrialização.

${ }^{94}$ CERVO, Amado Luiz. Política exterior e relações internacionais do Brasil: enfoque paradigmático. Revista Brasileira de Política Internacional, Brasília, v. 46, n.2, p. 5-25, jul./dez. 2003. p. 12.

${ }^{95}$ CERVO, Amado Luiz. Política exterior e relações internacionais do Brasil: enfoque paradigmático. Revista Brasileira de Política Internacional, Brasília, v. 46, n.2, p. 5-25, jul./dez. 2003. p. 13.

${ }^{96}$ CERVO, Amado Luiz. Política exterior e relações internacionais do Brasil: enfoque paradigmático. Revista Brasileira de Política Internacional, Brasília, v. 46, n.2, p. 5-25, jul./dez. 2003. p. 13. 
O período é marcado por um grande crescimento nacional; contudo, nos anos 70 e 80, o sistema internacional estava marcado pelo malogro decorrente da crise estrutural do capitalismo que estagnou. Após 1975, instalou-se uma profunda crise no país que não conseguia mais crescer. O elevado crescimento da dívida mostrou que o Brasil não tinha recursos para sustentar seu desenvolvimento. Todos os empréstimos em juros flutuantes feitos pelo Brasil converteram-se em dívida astronômica.

Por mais que a administração do Sarney tenha pagado 69 bilhões (45 só de juros) em dívidas externas, cerca de $60 \%$ do total da dívida herdada do governo anterior, seu governo repassou uma dívida de 115 bilhões de dólares, 10\% a mais do que os valores então devidos por Figueiredo ao governo posterior. Ou seja, quanto mais se pagava, ainda mais se devia. E mesmo assim, para pegar novos empréstimos para não "quebrar de vez", o Estado precisava se adequar aos caprichos dos credores. $^{97}$

Nesse sentido, o Brasil foi duramente explorado pelo capital financeiro internacional e acabou integralizado ao mercado de forma ainda mais negativa. Passou a resgatar as dívidas emitindo mais moeda e títulos. Em outras palavras, passou a saldar os juros com mais dívida, sendo obrigado a oferecer juros mais altos para atrair os compradores. Com isso, os preços das mercadorias aumentaram e a pressão inflacionária arruinava a economia. Em decorrência disso, esses títulos agravaram a dívida pública interna, empenhando recursos do orçamento governamental para saldar os compromissos. Foi preciso aumentar as exportações a qualquer custo, buscando internalizar divisas para saldar a balança de pagamentos. O agro-business recebeu incentivo governamental para exportar. Para resolver a crise das contas públicas, seguindo o FMI, houve as privatizações de empresas nacionais adquiridas por grupos multinacionais. Com isso, os grandes capitalistas, latifundiários e banqueiros internacionais passaram a ser os grandes ganhadores da dívida nacional. ${ }^{98}$

\footnotetext{
${ }^{97}$ OLIVEIRA, Ariovaldo Umbelino de. A inserção do Brasil no capitalismo monopolista mundial. In: ROSS, Jurandyr L. Sanches (Org.). Geografia do Brasil. São Paulo: USP, 2000. p. 304.

${ }^{98}$ OLIVEIRA, Ariovaldo Umbelino de. A inserção do Brasil no capitalismo monopolista mundial. In: ROSS, Jurandyr L. Sanches (Org.). Geografia do Brasil. São Paulo: USP, 2000.p. 304-307.
} 
Prismas: Dir., Pol. Publ. e Mundial., Brasília, v. 7, n. 1, p. 173-221, jan./jun. 2010 Hegemonia, internacionalização do estado e direito internacional segundo ...

Esse movimento foi congruente com o aparecimento de intelectuais que defenderam o pensamento neoclássico e com a eleição dos presidentes neoliberais na América Latina os quais foram eleitos para revolver a década perdida. $\mathrm{O}$ endividamento latino-americano tinha estagnado essas nações e as reduzido a "esmoleiros internacionais" 99

O Consenso de Washington ${ }^{100}$ receitou um projeto de recuperação desses países e os condicionou a anuírem a uma nova estrutura para recebimento de novos empréstimos. Essa prescrição é dividida em dez itens: disciplina fiscal para reduzir déficit público; supressão de subsídios e despesas públicas; reforma tributária (aumento de impostos); taxas de juros positivas; taxa de câmbio flutuante determinada pelo mercado; abertura do comércio exterior; abertura para investimentos diretos; privatizações; desregulamentação da atividade produtiva; e fortalecimento do direito de propriedade e segurança patrimonial. ${ }^{101}$

O mercado passou a ser o indutor do desenvolvimento. A abertura da economia (e integração bilateral ou regional) prometia um choque capaz de recuperar o crescimento e de renovar as estruturas locais. Porém, as privatizações, na prática, foram captadas por empresas estrangeiras, a abertura do mercado e dos bancos adaptou-se ao fluxo de capital especulativo. Naturalmente esses dois fenômenos naturalmente transferiram a renda ao centro. ${ }^{102}$ Portanto, somaram-se a outras duas formas de aglutinação de capital pelo centro, serviços da dívida e paraísos fiscais que remetem ativos nacionais ao exterior.

${ }^{99}$ CERVO, Amado Luiz. Política exterior e relações internacionais do Brasil: enfoque paradigmático. Revista Brasileira de Política Internacional, Brasília, v. 46, n.2, p. 5-25, jul./dez. 2003, p. 15-16.

100 "Opinião partilhada pelo Departamento de Tesouro, pelo Federal Reserve e pelo Departamento de Estado dos Estados Unidos, pelos ministérios das finanças dos demais países do Grupo dos Sete e pelos presidentes dos vinte maiores bancos internacionais permanentemente ouvidos por organismos multilaterais como o FMI, Banco Mundial, OMC. Segundo esse 'consenso', os problemas latino-americanos decorrem da estratégia de desenvolvimento adotada entre os anos 40 e 70, baseada nos modelos de industrialização acelerada via substituição de importações; ela teria resultado em um padrão de crescimento 'voltado para dentro', em más alocações de recursos, em escassez de poupanças disponíveis para o setor privado, em protecionismo e perda de competitividade externa, em inflação e corporativismo." FARIA, José Eduardo. O direito na economia globalizada. São Paulo: Malheiros, 2002. p. 165.

101 FARIA, José Eduardo. O direito na economia globalizada. São Paulo: Malheiros, 2002. p. 165.

102 CERVO, Amado Luiz. Política exterior e relações internacionais do Brasil: enfoque paradigmático. Revista Brasileira de Política Internacional, Brasília, v. 46, n.2, p. 5-25, Jul./dez. 2003, p. 18. 
Nesse sentido, as instituições políticas nacionais acabaram sendo reduzidas quanto ao seu poder de decisão autônoma em virtude do mercado. O Estado ainda legisla em várias matérias, mas diminuiu sua intervenção. Agora precisa compartilhar sua titularidade com outras agências privadas e públicas, estrangeiras e internacionais. É obrigado a levar em consideração o contexto econômico financeiro. Existe uma complexa rede de instituições e Estados que compartilham soberania e repartem também a capacidade de criar obrigações internacionais.

\section{Direito Internacional}

O ponto de partida para o entendimento do papel do Direito Internacional na teoria gramsciana é que a política, o Direito, a cultura e o conhecimento são partes constantes das relações internacionais que moldam as ações do atores. Cada ato é dependente das ideias que temos sobre as relações sociais. Portanto, os interesses dos atores não são exogenamente dados, mas refletem um entendimento sobre o mundo. $\mathrm{O}$ que leva à seguinte pergunta: quais são os interesses refletidos nas normas e políticas internacionais? ${ }^{103}$

A primeira resposta seria o da hegemonia. A nação hegemônica vai atingir suas metas pela coerção e pelo consentimento, vai utilizar-se de instituições, ideologias, ideias para levarem os demais atores a convergirem com seu interesse. ${ }^{104}$ Mas essa visão seria limitada por não enxergar que o Direito, como reino das ideias, possui uma capacidade de instrumentação emancipatória, e daí é importante a visão de Gramsci sobre o que é o Direito e quando ele pode ser um instrumento contra-hegemônico. ${ }^{105} \mathrm{O}$ Direito pode ser visto como elemento da cultura presente na sociedade civil, como veremos adiante, e esse local é privilegiado para deflagrar ações do poder estabelecido.

${ }^{103}$ WOODS, Ngaire. International political economy in an age of globalization. In: BAYLIS, John; SMITH, Steve. The globalization of world politics. New York: Oxford Press, 2006. p. 336-337.

${ }^{104}$ WOODS, Ngaire. International political economy in an age of globalization. In: BAYLIS, John; SMITH, Steve. The globalization of world politics. New York: Oxford Press, 2006. p. 336-337.

${ }^{105}$ REUS-SMIT, Christian. In: BAYLIS, John; SMITH, Steve. The globalization of world politics. New York: Oxford Press, 2006. p. 365. 
É evidente, portanto, que as forças do mercado e o poder hegemônico produzem a internacionalização do Estado, e, por consequência, brote a noção de obrigação internacional, isto é, Direito Internacional. Em outras palavras, internacionalização do Direito é correspondente ao alcance do Direito Internacional sobre o conteúdo do Direito Nacional, entretanto, não só isso, pois é um processo de mão dupla, já que os atores internacionais também levam suas necessidades nacionais para influenciar o Direito Internacional. ${ }^{106}$

Com isso em mente, adentra-se ao espectro do pensamento de "guerra de posição" expressa em Gramsci. A forma atual do Direito Internacional é prescrita pelas condições do pós-modernismo, conceituado dentro de um bloco histórico e hegemonia existente. Mas entender o Direito como um ser mutável possibilita uma abertura para o projeto de emancipação contra a lei e mediante a lei. ${ }^{107}$

Para Gramsci, o Direito dentro do Estado é coercitivo e consensual. Garante e avança os interesses econômicos das classes dominantes. Pelo Direito há a homogeneidade do conformismo social que é útil para desenvolvimento do grupo hegemônico. O Estado representa a força punitiva do sistema jurídico. O Estado perfeito seria aquele que exauriu todas as suas funções, desintegrando seu aparato estatal e jurídico que seriam absorvidos pela sociedade civil. ${ }^{108}$

O Direito também é elemento da sociedade civil e tem cunho educativo, transformando a necessidade de emprego de força em liberdade. A função do Direito Burguês, nesse sentido, pode ser entendida como uma busca dessa classe em educar e integrar as demais classes ao seu mundo. ${ }^{109}$

Cabe lembrar que hegemonia não é aliança de classes, o papel de ligar as classes é dos intelectuais, e, dessa forma, é importante compreender o papel do jurista como agente criador de um bloco ideológico no Direito. Para isso, utilizase de uma política para os intelectuais composta de filosofia e educação. O uso da

${ }^{106}$ CONI, Luís Claudio. A internacionalização do poder constituinte. Porto Alegre: S. A. Fabris, 2006. p. 68-69.

${ }^{107}$ CUTLER, Claire A. Gramsci, law, and the culture of global capitalism. Critical Review of International Social and Political Philosophy. [S.l.:s.n.], v. 8, n. 4, 2005. p. 529.

108 Apud. CUTLER, Claire A. Gramsci, law, and the culture of global capitalism. Critical Review of International Social and Political Philosophy. [S.1], v.8, n. 4, p. 530, 2005.

${ }^{109}$ Apud. CUTLER, Claire A. Gramsci, law, and the culture of global capitalism. Critical Review of International Social and Political Philosophy. [S.I], v.8, n. 4, p. 530, 2005. 
força seria o contrário, uma expressão da debilidade da hegemonia e passagem à ditadura.

Portanto, o Direito é a coerção estatal unida ao consentimento criado pela sociedade civil. O Direito, assim como as ideias, torna-se uma força histórica quando une a sociedade e a economia, por isso que não pode ser visto como um processo unicamente ético universal distanciado das relações econômicas do poder. Seu objetivo ético seria criar uma sociedade uniforme com aparente igualdade, mas a atual conjuntura burguesa esconde as diferenças classistas e sociais.

Gramsci afirma que o Estado deve criar novos tipos de civilização, adequar esta à moralidade das mais amplas camadas populares e às necessidades da continuidade do aparelho econômico de produção. A obtenção da colaboração dos atores desprezando a coerção é o papel do Direito. Direito deve ter seu conceito ampliado para incluir atividades que são parte do "indiferente jurídico", ou seja, fora da aceitação como fatos e atos relevantes ao Direito. Deve integrar atividades do domínio da sociedade civil, “que atua sem 'sanções' e sem 'obrigações' taxativas, mas que nem por isso deixa de exercer uma pressão coletiva e de obter resultados objetivos de elaboração nos costumes, nos modos de pensar e de atuar, na moralidade, etc.” Para exemplificar onde encontra esse espaço do Direito na sociedade, ele remete à "revolução permanente" conceito jacobino que descrevia o momento que não existiam grandes partidos ou sindicatos e a sociedade estava em fluidez, tempo em que o aparelho estatal francês era pouco desenvolvido e a sociedade civil mais autônoma. ${ }^{110}$ Ainda aponta que, na concepção de Direito, deveriam ser incorporadas "as atividades que 'premiam' indivíduos, grupos etc. premia-se a atividade louvável e meritória, assim como se pune a atividade criminosa e pune-se de modo original, fazendo-se com que intervenha a 'opinião pública' como instrumento de sanção."111

O Direito produz uma aparência de igualdade entre os atores. Todos passam a ser sujeito de direito e obrigações, o que os torna iguais perante a lei,

110 GRAMSCI, Antônio. Cadernos do Cárcere: Maquiavel. Notas sobre o estado e a política. Rio de Janeiro: Civilização Brasileira, 2000. p. 23-24.

111 GRAMSCI, Antônio. Cadernos do Cárcere: Maquiavel. Notas sobre o estado e a política. Rio de Janeiro: Civilização Brasileira, 2000. p. 28. 
Prismas: Dir., Pol. Publ. e Mundial., Brasília, v. 7, n. 1, p. 173-221, jan./jun. 2010 Hegemonia, internacionalização do estado e direito internacional segundo ...

contudo mascara a realidade de que sob o jugo capitalista existem diferentes classes e injustiças sociais. Essa forma de igualdade entre pessoas e nações é o que forma as relações jurídicas internacionais hoje generalizadas em termos de "juridificação". Globalização do Direito é “juridificação” da economia e sociedade em termos jurídicos de instituições e ideologias que penetram a ordem social e política internas, associando regulamentação jurídica com as relações sociais capitalistas. ${ }^{112}$

O Direito Burguês deriva do capitalismo; de sua forma igualitária que cria a ilusão que todos são iguais. Essa forma é repassada para o Estado, que o transforma em Direito Constitucional, Civil, Criminal, protegendo o indivíduo, a propriedade, e assegurando a posse. A lei influencia o capital e o Estado, e vice-versa. ${ }^{113}$

Esse Direito pós-moderno é pluralista e poroso, pois admite ordens subnacionais, nacionais, regionais, transnacionais e inter-relação entre todas elas. Regimes internacionais ligam todas essa pluralidade em espaços jurídicos, e a técnica e a comunicação fornecem a estrutura logística para operarem em tempo real.

Direito Internacional é o criador da mitologia e do entendimento comum que garante a legitimidade do bloco histórico contemporâneo. Racionaliza o mercado neoliberal, a competição global e eficiência econômica como normas básicas de um bloco histórico cada vez mais transnacional. ${ }^{114}$

A Teoria Neograsmciana enxerga que o Direito Internacional é uma força atuante, é importante, pois legitima a coerção internacional. Existe certa dificuldade dos neorrealistas de enxergarem que mesmo na anarquia internacional existe uma sociedade civil e um agrupamento de instituições que, mesmo rudimentares, conseguem impor alguma sanção, principalmente da opinião pública. E, ao mesmo tempo, promovem a consolidação do capital internacional. A existência de soft laws de regimes internacionais é expressão desse fenômeno, e experiência de códigos privados de comércio internacional, seguros e negócios é outra.

112 CUTLER, Claire A. Gramsci, law, and the culture of global capitalism. Critical Review of International Social and Political Philosophy, [S.1.], v.8, n.4, 2005. p. 532

113 CUTLER, Claire A. Gramsci, law, and the culture of global capitalism. Critical Review of International Social and Political Philosophy, [S.1.], v.8, n.4, 2005. p. 532.

114 CUTLER, Claire A. Gramsci, law, and the culture of global capitalism. Critical Review of International Social and Political Philosophy, [S.1.], v.8, n.4, 2005. p.535. 
O conceito de sociedade internacional da Escola Inglesa facilita essa concepção. Quando Estados e/ou pessoas levam em conta o comportamento dos outros e passam a reproduzir um diálogo por meio de regras comuns e instituições, o que fica evidenciado é uma sociedade. A Sociedade Internacional das Nações existe quando as unidades reconhecem umas às outras como unidades soberanas e estão preparadas para se tratarem em base comum de Direito. ${ }^{115}$

Outra ideia expressa por Alexandre Wendt da escola construtivista, também colabora com essa ideia - Anarchy is What States Make of It - ou seja, o sistema internacional não tem existência autônoma do atores e um sistema competitivo pode ser transformado em um cooperativo. ${ }^{116}$

Conduto, ainda se deve observar a questão da emancipação. Alerta-se que o Direito "não pode ser nem emancipatório nem não-emancipatório, porque emancipatório e não emancipatórios são os movimentos, as organizações, e os grupos [...] que recorrem à lei para levar suas lutas adiante." ${ }^{117}$ Destarte, a concepção de Direito pode ser resultante de domínio ou de liberdade. Enquanto, o capitalismo precisa de uma forma de Direito, existem grupos produzindo um Direito alternativo.

Cox aponta que uma das possíveis alternativas para uma nova ordem internacional seria o desenvolvimento de uma "contra-hegemonia" firmada em coalizões de países de terceiro mundo, visando a um desenvolvimento autônomo dos Estados periféricos e buscando extinguir a relação entre periferia e centro. ${ }^{118}$

Essa contra-hegemonia consiste em uma ordem alternativa, impulsionada por poderio suficiente capaz de desafiar o centro dominante. Apesar de essa nova ordem implicar em uma nova política econômica internacional, o futuro da "contra-hegemonia" depende das estruturas criadas no terceiro mundo. O controle, pela "hegemonia", de classes sociais nesses países, portanto, é importantíssi-

115 SARFATI, Gilberto. Teorias de relações internacionais. São Paulo: Saraiva, 2006. p.123.

116 WENDT apud VIOTTI, Paul R; KAUPI, Mark V. International relations theory: realism, pluralism, globalism, and beyond. 3. ed. Boston: Prentice Hall, 1998. p. 434.

117 SANTOS, Souza Boaventura. Poderá o direito ser emancipatório? Revista Crítica as Ciências Sociais. n. 65, maio 2003. p. 71.

118 COX, Robert W. Social forces, states and world orders: beyond international relations theory. In: COX, Robert; SINCLAIR, Timothy. Approaches to world order. Cambridge: Cambridge University Press, 1996. p. 115. 
mo, mas esse controle não pode ser pelo populismo. Já que a estrutura básica para transformação requer a participação de uma sociedade civil sólida guiada por uma "hegemonia” capaz de vinculá-las em uma direção cultural e moral comum.

Durante os anos 70, a Organização dos Países Exportadores de Petróleo - OPEP falhou em entender seu potencial como liderança. Permaneceu defendendo interesses das elites de seus países e ignorou a pobreza das demais classes. Devido a suas contradições internas, essas nações não conseguiram exercer uma supremacia internacional capaz de iniciar um programa para uma nova economia internacional.

Com isso em mente, o G77, UNCTAD, Grupos Cairns, BRICs, dentre outros arranjos institucionais compostos por system affecting states, devem saber de seus potenciais e, desse modo, assumir que suas ações podem favorecer uma nova ordem mundial, mas, para isso, alguns imediatismos devem ser esquecidos. Essas nações contrahegemônicas compostas de Estados, além disso, podem contar com atores não estatais, tais como: organizações não governamentais - ONGs, movimentos sociais, sindicatos.

Se o segredo da acumulação do capital é a posição monopolista, capacidade de gerar lucros extraordinários, os regimes jurídicos internacionais teriam pouca importância para o hegemon, pois, romper regras e instituições em nome próprio, sabendo navegar na contramão do mercado para ascender dentro da hierarquia mundial e manter os demais jogadores nas regras, seria o que forma um jogador vitorioso. $\mathrm{Ou}$ seja, a mobilidade do poder tem sido difícil e é praticamente impossível questionar o ordenamento do mercado se não for mediante uma grande potência. Isso leva a crer que a concepção do Direito Internacional é pouco influente, e que o poder é a chave do jogo de grandes nações.

Não se discorda que o poder é a chave das relações internacionais. Contudo, existem forças internacionais que impedem que o sistema internacional se atrofie. Primeiro, é a incapacidade de um agente concentrar fisicamente todos os poderes. Segundo, essa incapacidade de gestão do sistema mundial de forma concentrada somada à necessidade de expansão de capitais e truísmo que as elites das grandes potências buscam alianças para expandir seus mercados. A expansão do sistema sempre é movida pela competição por territórios políticos e econômicos, mas esses territórios precisam gozar de riqueza e estrutura suficientes que permitam a ampliação do sistema. Essa necessidade de parceria reproduz a lógica que novos jogadores serão incluídos no 
jogo. Foi isso que aconteceu, por exemplo, com a entrada dos EUA. De parceiro inglês, tornou-se líder do sistema.

Se os antigos parceiros conseguirem organizar suas forças sociais no sentido de ampliação do poder econômico e militar, certamente haverá um deslocamento dos centros de poder. É o próprio hegemon que organiza e mais tarde vê seu poder questionado pela elite local. Esse sistema não é determinista, mas depende de ações nacionais e internacionais.

A junção de atores mais fracos em busca do questionamento do poder mais forte é uma saída sempre possível em termos teóricos, tendo em vista que a expansão do mercado pelo hegemon inevitavelmente gera acumulação maior de recursos nessa nação. Desse ponto, os países periféricos ou semiperiféricos podem observar com clareza a desigualdade ou assimetria das relações, nasce no seio dessas relações a noção de injustiça. Esse é o conceito harmonizador dos interesses das nações subjugadas que deve passar a ser o objetivo final de qualquer aliança, isto é, corrigir injustiças. O simples questionamento da ordem vigente sem uma visão normativa de justiça é falha, pois reproduz as desigualdades internacionais.

Há dificuldades em aliar o interesse das novas elites nacionais que buscam questionar o status quo com aqueles movimentos sociais que busquem reduzir as injustiças sociais. Mas pela compreensão que o status quo só pode ser remodelado se houver capacidades suficientes das nações revolucionárias, e que o equilíbrio de poder é, em qualquer tempo ou local, a base da justiça social, somente através dessa haverá possibilidade de uma nova ordem mais justa. É no sentido de busca dessa justiça que o Direito apresenta-se como primordial instrumento de conscientização e padronização de ações mais equitativas. A crença não deve ser mantida na lei, mas no poder das ideias e das ações que, pautadas na justiça e no Direito Equitativo, provocam combustão social. É a visão de procurar a moralidade na realidade repleta de sentido concreto que possibilita uma escolha racional e guia as ações políticas que não são reflexo de percepções morais de uma única nação.

\section{Conclusão}

A Teoria Crítica de Gramsci fornece conhecimento sobre os elementos repressores da emancipação universal do homem. Permite refletir sobre o funciona- 
mento da ordem internacional e ao mesmo tempo interpreta a realidade política e oferece a ligação entre esse conhecimento e valores universais. Não se esquece também de elucidar que esse conhecimento é fruto de interesses particulares que podem ser universalizados, todavia jamais serão neutros.

Refuta o entendimento da imutabilidade da anarquia internacional pois reconhece que as grandes potências são grandes responsáveis pela ordem internacional, mas essa ordem não é imutável e totalmente subjugada pelos atores mais fortes. Distingue a ordem prevalecente das opções políticas e normativas capazes de transformar a realidade uma vez que a ordem atual é uma hegemonia de dominação política e econômica, a qual falha em promover a igualdade, não porque precisa de países pobres para explorar, mas porque é desigualitária por essência.

Seu objetivo teórico é apontar e escrutinar sistemas de pensamento e acontecimentos históricos que são compreendidos sem levar em consideração os interesses e possíveis alternâncias e preocupa-se em demonstrar alternativas que acarretem maior liberdade individual. Sendo assim, para mudar o mundo é imprescindível conhecer o mundo como ele é. Uma teoria crítica precisa equipar o analista com um relato histórico da origem e evolução da ordem vigente para apresentar uma análise das possíveis transformações sociais. Buscar entender a ordem é o que nos impede de desdenhar por ideias normativas ilusórias. Trate-se, pois, de uma compreensão utópica delimitada. ${ }^{119}$

O fenômeno da hegemonia, da internacionalização do Estado e do Direito Internacional são compreendidos em nossos tempos por aquilo que entendemos como globalização. Essa é uma chave do pensamento sobre relações internacionais: conceituar globalização e tentar trazer ao entendimento a realidade internacional. As categorias teóricas de Gramsci fornecem elementos excelentes para compreensão do fenômeno. Suas teorias apresentam uma estrutura básica para examinar as relações existentes entre as forças materiais de produção, ideias e instituições em um determinado período histórico.

De forma breve, analisou-se a pax britannica, a pax americana e a decorrência da globalização. A base do apresentado é que as forças sociais formam a

${ }^{119}$ DEVETAK, Richard. Critical theory. In: BURCHILL, Scoot; LINKLATER, Andrew. Theories of international relations. New York: St. Martin's Press, 1995. p. 155. 
base material das relações humanas. Da consideração histórica das relações internacionais se extrai que a sociedade civil e o Estado são intimamente ligados e que diferentes formas de sociedades produzem diferentes Estados. Isso reflete na ordem mundial, porquanto mudanças na balança de poder são indícios de mudanças nas relações sociais. Do outro lado, as forças sociais são influenciadas pela ordem internacional, composta de Estados, e pelas forças produtivas.

Para averiguar o poder nessas relações, utiliza-se do conceito de hegemonia. Hegemonia é o reflexo entre poder material, ideologias e instituições. A hegemonia infiltra em toda ordem prevalecente.

Ao mesmo tempo, existe uma contra-hegemonia, forças sociais comprometidas em questionar a hegemonia. São essas movidas por contradições do próprio sistema hegemônico que produzem rupturas com a ordem mundial.

As forças sociais, buscando uma realidade mais equalitária, devem montar uma "guerra de posição". A globalização hegemônica pode ser atenuada pela globalização de baixo para cima. Nesse contexto, convém ressaltar o Direito Internacional como uma categoria que deveria ser utilizada para transformação social, já que é meio inseparável das ações estatais internacionais.

O Direito Internacional pode ser a forma de reestruturação do relacionamento entre os Estados e a economia internacional. A internacionalização do Estado é marcada pela erosão do papel de guarda dos interesses nacionais sobre os internacionais. A contradição do sistema atual é seu déficit democrático e incapacidade de inclusão social. Portanto, em favor das redes econômicas internacionais, há intensificação das fontes transnacionais de decisão. É nesse campo que o Direito Internacional possui papel inegável.

Da aproximação direta entre os indivíduos e os movimentos internacionais é cogente que o reducionismo do Estado não se transforma ao mesmo tempo em redução dos Direitos dos Povos. Não se pode negar que a exclusão social seja também decorrente da transnacionalização do território político-econômico. Por isso, os mecanismos jurídicos devem se utilizar de regras compensatórias para neutralizar a exclusão e assegurar aos Estados um aumento em seu campo de ação contrapondo-se ao objetivo de igualdade formal. 
Os Estados, dessa forma, não podem somente reproduzir as regras do jogo econômico, mas alterá-las. E somente em ações em conjunto em nível internacional, mas sempre iniciadas em um determinado modelo de Estado é que se apresenta uma alternativa ao modelo atual. Diante do exposto, no caso brasileiro, como o “território é um território nacional da economia internacional”, tem-se a realidade que devemos compensar as mazelas do sistema internacional no nível nacional e buscar reduzir as próprias mazelas provocadas em nível nacional sem deixar de mover-se no jogo mais amplo.

Com isso em mente, é mandatório um projeto nacional que não seja similar aos projetos hegemônicos atuais. As necessidades dos Estados nacionais devem ser atendidas, mas o interesse nacional não pode ser somente baseado no interesse próprio de curto prazo, mas no interesse pela reformulação da ordem mundial e construção de um sistema mais justo.

Os Estados, sem comprometer a justiça, ainda podem balancear as pressões internacionais com as necessidades internas de cada nação. A estrutura internacional não impede que ações estatais construam uma realidade alternativa e mais justa.

\section{Hegemony, Internationalization of the State and International Law according to Neogramscian Theory.}

\section{Abstract}

This paper discusses the Neogramscian Theory on international relations. The main focus is the "internationalization of the State" as a phenomenon produced by the interaction of material forces, ideologies and institutions. It aims to exam the configuration of human relations especially those guided by hegemonic movements. These movements lay down the foundation of an international network system which consists of states and international institution that shape the perception of "international obligation". Through a theoretical background of the works of Gramsci and Cox, it reviews the Pax Britannica and Pax Americana to enhance the study of today's globalization, also contained herein. Finally, there are remarks on Law as a potential counter-hegemonic element and as harmonizer of social relations. It discusses the possibility of changes in the current international 
order. It asserts that hegemonic globalization can be mitigated through globalization from below. In this context, International Law may be an instrument of social transformation. It may reconstruct the relation among States and the international economy. It concludes that an alternative globalization depends on action guided by counter-hegemonic organizations, groups, States that can produce an alternative Law.

Keywords: Hegemony. Internationalization of the State. Globalization. Neogramscian Theory. International Law.

\section{Referências}

AUGELLI, Enrico; Murphy, Graig N. Augelli. Gramsci and international relations: a general perspective and example from recent US policy towards the third world. In: GILL, Stephen. Gramsci, historical materalism and international relations. Cambrigde: Cambrigde University Press, 1993.

BOBBIO, Norberto. Ensaios sobre Gramsci e o conceito de sociedade civil. São Paulo: Paz e Terra, 1999.

BOBBIO, Norberto; MATTEUCI, Nicola; PASQUINO, Gianfranco. Dicionário de política. Brasília: UnB, 2000.

BURNS, Edward Mcnall; LERNER, Robert E; MEACHAM, Standish. História da civilização ocidental. São Paulo: Globo, 2005. v. 2.

CASTELLS, Manuel. Global Governance and Global Politics. Political Science \& Politics, [S. 1.], v. 38, n. 1, jan. 2005, p. 10. Disponível em: <http://www. manuelcastells. info/en/obra_02.htm> Acesso em: 1 jun. 2009.

CERVO, Amado Luiz. Hegemonia coletiva e equilíbrio: a construção do mundo liberal (1815-1871). In: SARAIVA, José Flávio Sombra. (Org.) Relações internacionais dois séculos de história: entre a preponderância européia e a emergência americana (1815-1947). Brasília: IBRI, 2001. v. 1. p. 61-71.

CERVO, Amado Luiz. Hegemonia coletiva e equilíbrio: a construção do mundo liberal (1815-1871). In: SARAIVA, José Flávio Sombra (Org.). Relações internacionais dois séculos de história: entre a preponderância européia e a emergência americana (1815-1947). Brasília: IBRI, 2001. v. 1. 
CERVO, Amado Luiz. Política exterior e relações internacionais do Brasil: enfoque paradigmático. Revista Brasileira de Política Internacional, Brasília, v. 46, n.2, jul./dez. 2003.

CERVO, Amado Luiz; BUENO, Clodoaldo. História da política exterior do Brasil. Brasília: UnB, 2002.

CONI, Luís Claudio. A internacionalização do poder constituinte. Porto Alegre: S. A. Fabris, 2006.

COUTINHO, Carlos Nelson. As categorias de Gramsci e a realidade brasileira. In: COUTINHO, Carlos Nelson; NOGUEIRA, Marco Aurélio (Org.). Gramsci e a América Latina. São Paulo: Paz e Terra, 1993.

COX, Robert W. Critical political economy. In: HETTNE, Björn (Ed.) International political economy: understanding global disorder. Halifax: Fernwood, 1995.

COX, Robert W. Gramsci, hegemony and international relations: an essay in method. In: GILL, Stephen. Gramsci, historical materalism and international relations. Cambrigde: Cambrigde University Press, 1993.

COX, Robert W. Rumo a uma concepção pós-hegemônica de ordem mundial: reflexões sobre a relevância de Ibn Kaldun. In: ROSENAU, James N.; CZEMPIEL, Ernst-Otto. Governança sem governo: ordem e transformação na política mundial. Brasília: UnB, 2000.

COX, Robert W. Social forces, states and world orders: beyond international relations theory. In: COX, Robert; SINCLAIR, Timothy. Approaches to world order. Cambridge: Cambridge University Press, 1996.

CUTLER, Claire A. Gramsci, law, and the culture of global capitalism. Critical Review of International Social and Political Philosophy. [S.l.], v. 8, n. 4, 2005.

DEVETAK, Richard. Critical theory. In: BURCHILL, Scoot; LINKLATER, Andrew. Theories of international relations. New York: St. Martin's Press, 1995.

FUNDO MONETÁRIO INTERNACIONAL. Disponível em: <http://www. imf. org /external/np/ sec/memdir/members.htm>. Acesso em: 15 jul. 2009.

FARIA, José Eduardo. O direito na economia globalizada. São Paulo:

FIORI, José Luís. O poder americano. Petrópolis: Vozes, 2004. 
CUTLER, Claire A. Gramsci, law, and the culture of global capitalism. Critical Review of International Social and Political Philosophy. [S. 1.], v. 8, n. 4, 2005. p. 535.

GRAMSCI, Antônio. Cadernos do Cárcere: Maquiavel. Notas sobre o estado e a política. Rio de Janeiro: Civilização Brasileira, 2000.

GRIFFITHS, Martin. 50 grandes estrategistas das relações internacionais. São Paulo: Contexto, 2004.

HOBDEN, Stephen; JONES, Richard Wyn. Marxist theories of international relations. In: BAYLIS, John; SMITH, Steve. The globalization of world politics. New York: Oxford Press, 2006.

JARDIM, Tarciso Dal Maso. Gramsci, teoria ampliada do estado e as relações internacionais. Revista Universitas Relações Internacionais, Brasília, n. 1, p. 5-25, jul./dez. 2002.

KRUGMAN, Paul R.; OBSTFELD, Maurice. Economia internacional: teoria e prática. São Paulo: Pearson, 2005.

MAIA, Jayme de Mariz. Economia internacional e comércio exterior. São Paulo: Atlas, 2007.

MAQUIAVEL, Nicolau. O príncipe. São Paulo: Germape, 2003.

MCGREW, Anthony. Globalization and global politics. In: BAYLIS, John; SMITH, Steve. The globalization of world politics. New York: Oxford Press, 2006.

NYE, Joseph S. Junior. O paradoxo do poder americano: porque a única superpotência do mundo não pode prosseguir isolada. São Paulo: UNESP, 2002.

OLIVEIRA, Ariovaldo Umbelino de. A inserção do Brasil no capitalismo monopolista mundial. In: ROSS, Jurandyr L. Sanches (Org.). Geografia do Brasil. São Paulo: USP, 2000.

OLIVEIRA, Ariovaldo Umbelino de. A mundialização do capitalismo e a geopolítica no fim do século XX. In: ROSS, Jurandyr L. Sanches (Org.). Geografia do Brasil. São Paulo: USP, 2000.

OLIVEIRA, Ariovaldo Umbelino de. A mundialização do capitalismo e a geopolítica no fim do século XX. In: ROSS, Jurandyr L. Sanches (Org.). Geografia do Brasil. São Paulo: USP, 2000. 
PORTELLI, Hugues. Gramsci e o bloco histórico. Rio de Janeiro: Paz e Terra, 1990.

REUS-SMIT, Christian. In: BAYLIS, John; SMITH, Steve. The globalization of world politics. New York: Oxford Press, 2006.

ROSENAU, James N; CZEMPIEL, Ernst-Otto. Governança sem governo: ordem e transformação na política mundial. Brasília: UnB, 2000.

SANTOS, Milton. Por uma outra globalização: do pensamento único à consciência universal. Rio de Janeiro: Record, 2002.

SANTOS, Souza Boaventura. Poderá o direito ser emancipatório? Revista Crítica as Ciências Sociais, [S.1.], n. 65, maio 2003.

SARFATI, Gilberto. Teorias de relações internacionais. São Paulo: Saraiva, 2006.

SILVA, Marco Antonio de Menesses. Teoria crítica em relações internacionais. [versão não publicada]

TAYLOR, Paul; CURTIS, Devon. The United Nations. In: BAYLIS, John; SMITH, Steve. The globalization of world politics. New York: Oxford Press, 2006.

VIOTTI, Paul R; KAUPI, Mark V. International relations theory: realism, pluralism, globalism, and beyond. 3. ed. Boston: Prentice Hall, 1998.

WOODS, Ngaire. International political economy in an age of globalization. In: BAYLIS, John; SMITH, Steve. The globalization of world politics. New York: Oxford Press, 2006. 
